WORKING PAPER NO. 151

INDIA'S GLOBAL TRADE POTENTIAL: THE GRAVITY MODEL APPROACH

Amita Batra

DECEMBER 2004

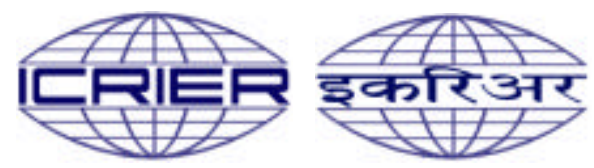

INDIAN COUNCIL FOR RESEARCH ON INTERNATIONAL ECONOMIC RELATIONS

Core-6A, 4th Floor, India Habitat Centre, Lodi Road, New Delhi-110 003

Website 1: www.icrier.org, website 2: www.icrier.res.in 
INDIA'S GLOBAL TRADE POTENTIAL: THE GRAVITY MODEL APPROACH

Amita Batra

DECEMBER 2004

The views expressed in the ICRIER Working Paper Series are those of the author(s) and do not necessarily reflect those of the Indian Council for Research on International Economic Relations (ICRIER). 


\section{Contents}

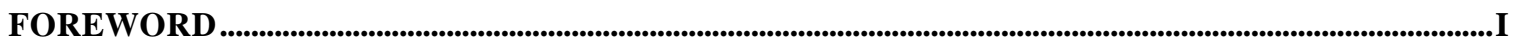

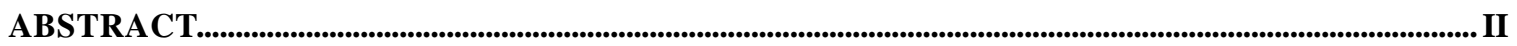

I INTRODUCTION .....................................................................................................................................................

I THE GRAVITY MODEL ............................................................................................................................2

II SURVEY OF LITERATURE........................................................................................................................................5

III OUR APPROACH............................................................................................................................6

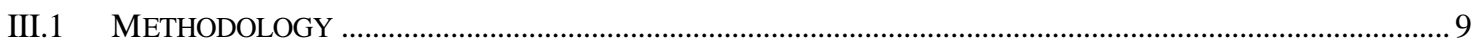

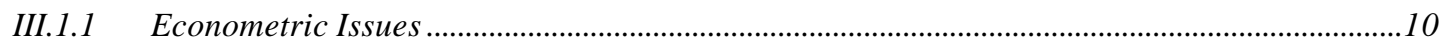

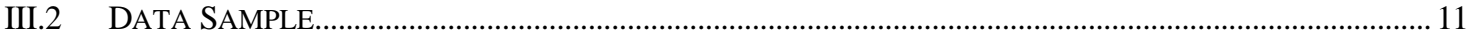

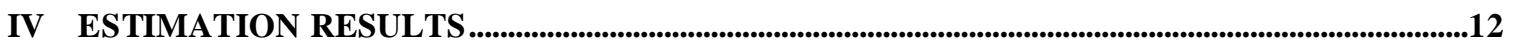

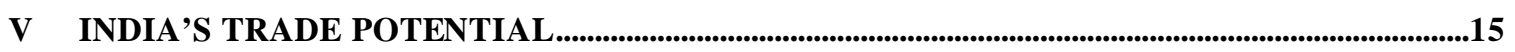

V.1 REGIONAL DISTRIBUTION OF INDIA'S TRADE POTENTIAL .............................................................. 16

V.2 INDIA'S TRADE POTENTIAL WITH REGIONAL GROUPINGS IN ASIA .................................................... 17

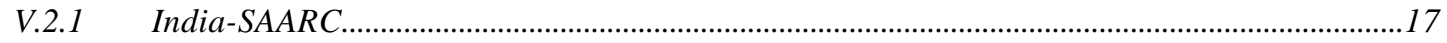

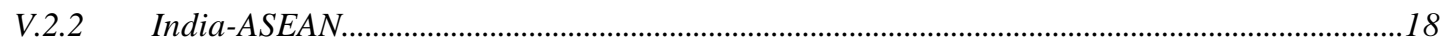

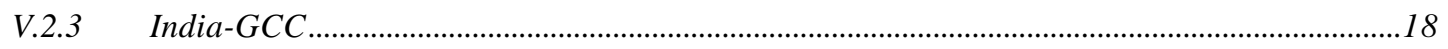

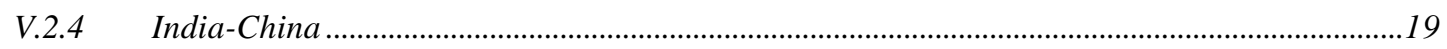

VI CONCLUSIONS .................................................................................................................................................................19

REFERENCES ................................................................................................................................................................................21

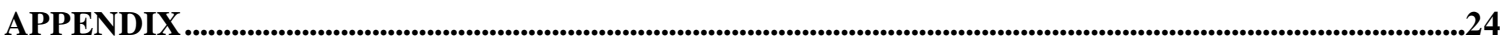

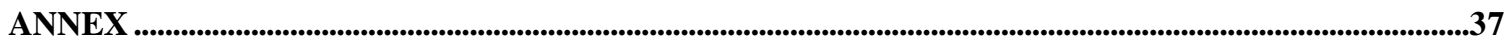




\section{Foreword}

The comprehensive programme of trade liberalization initiated in India in July 1991 has no doubt, led to a perceptible change in the performance of the external sector. Current account deficits have fallen sharply and reserves are accumulating. Though our share of world trade has almost doubled as the base was small it is still not commensurate with our position as the $11^{\text {th }}$ largest economy in terms of the current exchange rate $\left(4^{\text {th }}\right.$ in terms of GDP at PPP). Similarly, though our trade to GDP ratio has increased it is still far below other large economies such as China and Brazil. Clearly, therefore India needs to enhance its volume of trade with the rest of the world. This paper undertakes an estimation of India's global trade potential and is therefore topical.

To estimate the global trade potential for India this paper has used an augmented gravity model equation with maximum possible geographical coverage of world trade flows. Bilateral trade in the model has been explained using variables that are representative of geographical, cultural and historical proximity of bilateral trade pairs along with their economic size. In the process the model estimates the most natural trading partners for India. The paper identifies countries, regions and regional groupings in Asia with maximum potential for expansion of trade with India.

The estimates obtained using the augmented gravity model specification in this paper indicate a huge potential, of the order of US \$ 6.5 billion, with Pakistan. The model also shows that there is tremendous potential with China and trade can more than double if barriers and constraints are removed.

The potential direction of trade indicated by the findings in this paper assumes great importance in the context of India's ongoing efforts of bilateral and regional integration. I am confident that this paper will provide an important contribution in shaping India's policy of country specific trade promotion and bilateral integration.

Arvind Virmani

Director \& Chief Executive

ICRIER

December 2004 


\title{
India's Global Trade Potential: The Gravity Model Approach
}

\author{
Amita Batra*
}

\begin{abstract}
In this paper we have attempted to estimate trade potential for India using the gravity model approach. We have used an augmented gravity model to first analyze the world trade flows and the coefficients thus obtained are then used to predict trade potential for India.

The gravity model has been estimated using the OLS technique with cross section data for the year 2000. The dependent variable in all our tests is total merchandise trade (exports plus imports in US dollars), in log form, between pairs of countries.

Our estimation results show that the gravity equation fits the data and delivers precise and plausible income and distance elasticities and estimates for other geographical, cultural and historical characteristics. All three of the traditional "gravity" effects are intuitively reasonable, with statistically significant t-statistic. Alternative measures of GNP in terms of current dollar value and purchasing power parity do not alter either the sign or significance of different explanatory variables.

The magnitude of India's trade potential is highest with the Asia-Pacific region followed by Western Europe and North America. Countries like China, United Kingdom, Italy and France reveal maximum potential for expansion of trade with India. Among specific country groupings/trade arrangements, India's trade potential is revealed to be highest with Pakistan in SAARC and with Philippines and Cambodia in the ASEAN.
\end{abstract}

Key Words: Gravity Model, Trade Potential

JEL Classification: F10, F13, F15

\footnotetext{
* The idea of estimating India's global trade potential using the Gravity Model by ICRIER was first thought of by Prof. Arvind Virmani. I am indeed thankful for his giving me the opportunity to undertake this work. The paper as finalized reflects also Prof. Arvind Virmani's valuable suggestions at various stages. My sincere thanks to the participants at the ICRIER seminar for giving useful comments. Ms. Zeba Khan worked hard to assist me in finalizing this paper for which I offer my deep appreciation.
} 


\section{Introduction}

Trade reforms formed an integral part of the comprehensive programme of structural reforms initiated in India in 1991-92. These reforms have led to a perceptible change in the performance of the external sector in India. This is evident from the increase in trade to GDP ratio in India. From a pre -reform ratio (1980-1991) of 14 per cent, trade to GDP ratio increased to 23 per cent in the period of reforms (1991-2003). India's exports as a percentage of world exports improved to .56 per cent during 1991-96 and further to .65 per cent during 1996-2002 from .48 per cent in the 1980s. The ratio was .71 per cent in 2001-2002, the highest achieved so far since the 1970s. However, India's share in world trade is still very low and appears unimpressive when compared with other Asian countries such as China, Malaysia, Korea and Thailand ${ }^{1}$. India's share in world trade is less than one per cent. In comparison, China corners about 5 per cent of world trade and Korea has a 2.5 per cent share in total world trade There is, therefore, a clear need to enhance the volume of India's trade with the rest of the world. In this context an estimation of India's trade potential is appropriate.

This paper aims to estimate trade potential for India using the gravity model approach. Gravity model is one of the most popular empirical tools for modeling bilateral trade flows. We use the gravity model to first analyze the world trade flows for the year 2000. The coefficients thus obtained from the gravity model estimation are then used to predict trade potential for India.

Untapped trade potential is indicated in case India's trade with any country is less than that predicted by the gravity model. The policy implications associated with the findings of untapped trade potential would extend from the necessity of country specific trade promotion and bilateral integration to the need to anticipate relevant distributional changes due to the effect of the expansion in bilateral trade flows in the near future.

\footnotetext{
${ }^{1}$ Share of select East Asian countries in World exports and trade is presented in Annex Table I.
} 
The remainder of the paper is organized as follows. In the next section an introduction to the gravity model and its theoretical foundations are presented. Section three briefly reviews the existing literature on the application of gravity model to international trade flows. In section four we present an outline of our approach, methodology, main econometric issues and data sample for estimation of the gravity model. Results are analyzed in section five. In section six we discuss India's trade potential with countries in SAARC, ASEAN and GCC. Section seven concludes.

\section{The Gravity Model}

The gravity equation is a simple empirical model for analyzing bilateral trade flows between geographical entities. The gravity model for trade is analogous to the Newtonian physics function that describes the force of gravity. The model explains the flow of trade between a pair of countries as being proportional to their economic "mass" (national income) and inversely proportional to the distance between them. The model has a lineage that goes back to Tinbergen (1962) and Poyhonen (1963), who specified the gravity model equation as follows:

$$
\text { Trade }_{i j}=\alpha \cdot \frac{\text { GDP }_{i} \cdot G^{-G P}}{\text { Distance }_{i j}}
$$

where Trade $_{i j}$ is the value of the bilateral trade between country $i$ and $j, G P_{i}$ and GDP $_{j}$ are country $\mathrm{i}$ and j's respective national incomes. Distance $\mathrm{ij}_{\mathrm{j}}$ is a measure of the bilateral distance between the two countries and $\alpha$ is a constant of proportionality.

Taking logarithms of the gravity model equation as in (1) we get the linear form of the model and the corresponding estimable equation as:

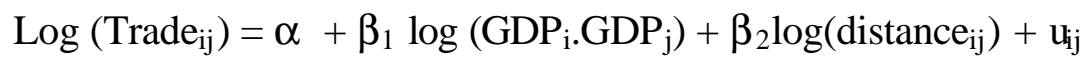


Where $\alpha, \beta_{1}$ and $\beta_{2}$ are coefficients to be estimated. The error term captures any other shocks and chance events that may effect bilateral trade between the two countries. Equation (2) is the core gravity model equation where bilateral trade is predicted to be a positive function of income and negative function of distance.

\section{Theoretical Foundations}

While the core gravity equation has been used for empirical analysis since the econometric studies of trade by Tinbergen (1962) and Poyhonen (1963), the theoretical foundations to the model are of more recent origin. The most classic and early application of the model to international trade was perhaps by Linnemann (1966).

Trade theorists have found the model to be consistent with theories of trade based upon models of imperfect competition and with the Hecksher - Ohlin model. Frankel (1997) credits Helpman and Krugman (1985) for the standard gravity model. The derivation of a proportionate relationship between trade flows and country size as given by Helpman do not include a role for distance. There are several reasons, though, for the inclusion of distance as an explanatory variable. Some of these explanations are as follows:

Distance is a proxy for transport costs

Distance is an indicator of the time elapsed during shipment. For perishable goods the probability of surviving intact is a decreasing function of time in transit

$>$ Synchronization costs: when factories combine multiple inputs, the timing of these needs to be synchronized so as to prevent emergence of bottlenecks. Synchronization costs increase with increasing distance.

$>$ Transaction costs: distance may be correlated with the costs of searching for trading opportunities and the establishment of trust between potential trading partners.

> Cultural distance: It is possible that greater geographical distance is correlated with larger cultural differences. Cultural differences can impede trade in many ways such as inhibiting communication, clashes in negotiating styles etc. 
Bergstrand's (1985) version of the imperfect substitutes theory incorporated a role for shipping costs, proxied in practice by distance. More recently, Deardorff (1995) has derived the gravity model from Hecksher-Ohlin theory. Deardorff shows that the gravity model can be derived from two extreme cases of the classical framework of the Hecksher-Ohlin model. The first case is frictionless trade, in which the absence of all impediments to trade in homogenous products causes producers and consumers to be indifferent among trading partners. Resolving this indifference randomly expected trade flows correspond exactly to the simple frictionless gravity equation if preferences are identical and homothetic or if demands are uncorrelated with supply and they depart from that equation systematically when there are such correlations. The second case is that different countries produce distinct goods, as in the $\mathrm{H}-\mathrm{O}$ model with complete specialization. Expression for bilateral trade are derived, first with Cobb-Douglas preferences and then with CES preferences. Distance is included in the second of the two models.

Trade theories based upon imperfect competition and the Hecksher-Ohlin model justify the inclusion of the core variables -income and distance. Most studies have however, included additional variables to control for differences in geographic factors, historical ties and at times economic factors like the overall trade policy and exchange rate risk.

The particular theoretical model that best describes the empirical findings of the gravity model is a matter of contention. The main point, however, is that it seems possible to derive the gravity model equation from a variety of leading theories. The equation, it is often said, has gone from an amazing poverty of theoretical foundations to an embarrassment of riches!

The gravity model of international trade has a remarkably consistent history of success as an empirical tool. The elasticities of trade with respect to both income and distance are consistently high, signed correctly and statistically significant in an equation that explains a reasonable proportion of the cross-country variation in trade. It is to be noted however, that, in analyzing trade between country $\mathrm{A}$ and $\mathrm{B}$, the gravity model 
makes no provision for third party effects i.e. the model does not take into account the conditions and opportunities that prevail between $\mathrm{A}$ and $\mathrm{C}$ and $\mathrm{B}$ and $\mathrm{C}$.

\section{Survey of Literature}

Among the many studies using the gravity framework, a high percentage shares the research task of predicting trade potentials. Rahman (2003) has estimated trade potential for Bangladesh using panel data approach with economic factors like openness, exchange rates etc rather than natural factors. Christie (2002) estimates trade potential for Southeast Europe using ordinary least square estimation on cross section data from 199699. Kalbasi (2001) has analyzed the volume and direction of trade for Iran in a 76 country sample. The group of countries has been divided into developing and industrial countries and trade flows have been examined to determine the impact, if any, of the stage of development on bilateral trade.

Several studies have analyzed the trade enhancing impact of preferential trading arrangements. These studies predict the additional bilateral trade that would be a consequence of the economic integration of a set of economies. Both the cross section and panel data approach has been used by these studies. The cross-section as also the panel data approach is mainly static and refers to a long run relationship. Frankel (1997) has used the gravity model to investigate a host of issues like the estimates of trading blocs, role of currency links etc using cross-section and panel data. Frankel and Wei (1993) have examined bilateral trade patterns throughout the world and analyzed the impact of currency blocs and exchange rate stability on trade.

The most recently developed gravity model, by UNCTAD-WTO Trade Centre is TradeSim. This is being used for the estimation of trade potentials for countries with limited trade relations in the past, in particular transition economies. The model is in general being used to analyze the bilateral trade flows of developing countries with their trading partners. 


\section{Our Approach}

In addition to the basic gravity model equation we estimate an augmented gravity model equation to first analyze international trade flows and then estimate the trade potential for India with its trading partners. The model is "augmented" in that, several conditioning variables that account for other factors that may affect trade have been included over and above the (the natural logarithms of) income and distance. The modelsbasic and augmented as formulated for estimation are as follows:

\section{Basic Gravity Model}

As stated in section II, the gravity model in its most basic form explains bilateral trade $\left(\mathrm{T}_{\mathrm{ij}}\right)$ as being proportional to the product of GDPiand GDP $\mathrm{j}$ and inversely related to the distance between them.

$\log (\mathrm{Tij})=\alpha+\beta_{1} \log \left(\mathrm{GDP}_{\mathrm{i}} \mathrm{GDP}_{\mathrm{j}}\right)+\beta_{2} \log \left(\mathrm{GDP} /\right.$ pop $\left._{\mathrm{i}} . \mathrm{GDP} / \mathrm{pop}_{\mathrm{j}}\right)+\beta_{3} \log \left(\mathrm{Dist}_{\mathrm{ij}}\right) \ldots \ldots$ (3)

To account for other factors that may influence trade levels, dummy variables have been added to the basic model. The augmented gravity equation is thus expressed as follows:

Augmented gravity model:

$$
\begin{gathered}
\log (\mathrm{Tij})=\alpha+\beta_{1} \log \left(\mathrm{Y}_{\mathrm{i}} \mathrm{Y}_{\mathrm{j}}\right)+\beta_{2} \log \left(\mathrm{Y}_{\mathrm{i}} / \mathrm{pop}_{\mathrm{i}} . \mathrm{Y}_{\mathrm{j}} / \mathrm{pop}_{\mathrm{j}}\right)+\beta_{3} \log \left(\mathrm{D}_{\mathrm{ij}}\right)+\beta_{4}\left(\text { Border }_{\mathrm{ij}}\right)+\beta_{5} \\
\left(\operatorname{Lang}_{\mathrm{ij}}\right)+\gamma_{1}(\mathrm{Regl})+\gamma_{2}(\mathrm{Comcol})+\gamma_{3}(\mathrm{Col})+\gamma_{4}(\text { landlocked })+\gamma_{5}(\text { Island })+\mathrm{u}_{\mathrm{ij}} \ldots \ldots \ldots \text {. }(4)
\end{gathered}
$$

Where $\mathrm{i}$ and $\mathrm{j}$ denotes countries and Tij denotes the value of bilateral trade between $\mathrm{i}$ and $\mathrm{j}$. The explanatory variables in the gravity model are defined as follows:

GNP (Y)/Population (Pop): There are two standard ways of measuring the size of countries in the gravity model: GNP (output) or population. We have also attempted to supplement the size variables with a measure of land area. This however does not add any 
significant value to our analysis. The focus in this paper is thus on GNP as a measure of size and self- sufficiency with an alternative tests using population.

As regards GNP, the model is estimated using nominal GNP in US dollars and also GNP in terms of purchasing power parity (PPP). The main assumption is that trade usually happens at international prices, and so GNP at PPP has no bearing on trade levels. At the same time, given the strong under-valuation of certain countries' GNP, importantly for India, it is tempting to estimate the model with GNP at PPP and observe if the corresponding coefficients change in any significant fashion.

Per Capita Income: Y/POP: While mathematically, it is precisely equivalent, whether we express the explanatory variables as GNP and per capita GNP, or as GNP and population, we choose the former. In particular the specification with GNP per capita allows us to explore the link between a country's trade and its stage of development. Several explanations have been provided in the literature for inclusion of GNP per capita as an independent variable in addition to GNP. One possible explanation for the independent effect of per capita income is that exotic foreign varieties of goods are superior in consumption. Other possibilities arise out of the literature on endogenous growth. For e.g. the process of development may be led by the innovation or invention of new products that are then demanded as exports by other countries.

It is also instructive to focus explicitly on GNP per capita as a determinant of trade. The standard gravity model predicts that countries with similar levels of output per capita will trade more than countries with dissimilar levels. This is true of the HelpmanKrugman sort of theory also, as it predicts that the volume of trade should increase with increasingly equal distribution of national income. This however contradicts the traditional Hecksher-Ohlin theories of trade that predict that countries with dissimilar levels of output will trade more than countries with similar levels. In addition, the Linder hypothesis says that countries with similar levels of per capita income will have similar preferences and similar but differentiated products, and thus will trade more with each other. This hypothesis is often viewed as similar to the Krugman-Helpman theory in its predictions. While the Krugman - Helpman hypothesis predicts that the sum of the logs 
of (GNP/popi) and (GNP/popj) will have a positive effect on the log of trade, the Linder hypothesis is associated with the prediction that the absolute value of the difference of the two variables will have a negative effect on trade. A positive value of this falls in the category of Hecksher - Ohlin theories.

To distinguish among these influences - Hecksher-Ohlin style factor endowments differences, Linder -style taste differences, and the effect of development on trade and in an attempt to capture the distinctive features of each, we add a term for the difference in per capita GNP in the standard formulation of the gravity model. A negative sign on this term would support the Linder hypothesis, while a positive sign would support the Hecksher-Ohlin hypothesis. We test for both the hypotheses.

Distance: D is the distance between country $\mathrm{i}$ and country $\mathrm{j}$ measured "as the crow flies"-technically called the great-circle distance measured between the two latitude-longitude combinations. A major proportion of trade today goes by air (and not by sea or land) and therefore the air routes provide the most convenient justification for using the straight - line or great -circle measure of distance. The ultimate justification is of course given by the fact that this measure seems to be a reasonable measure of averaging across different modes of transportation and works well in practice.

To capture the impact of geographical factors and historical ties between countries on bilateral trade we include dummy variables. These are explained as follows:

Borderl Adjacency: A dummy variable to identify a pair of countries that are adjacent or contiguous or share a border. This dummy is in addition to the inclusion of the distance variable to account for the possibility of centre- to-centre distance overstating the effective distance between neighboring countries that may often engage in large volumes of border trade. The dummy variable is unity if countries $i$ and $j$ share a common border and 0 when they do not. 
Common language: Lang $_{\mathrm{ij}}$ : is equal to one when two countries share a common language (official or commercial): Common language is expected to reduce transaction costs as speaking the same language helps facilitate trade negotiations.

Colonial links: Shared history is expected to reduce transaction costs caused by cultural differences.

- Comcol.: is equal to one if $\mathrm{i}$ and $\mathrm{j}$ were colonies after 1945 with the same colonizer

- Col.: is equal to one if $\mathrm{i}$ colonized $\mathrm{j}$ or vice versa

Landlocked: number of landlocked countries in the pair

Island: number of countries in the pair that are islands

Regional trading arrangements: Regl: Countries often enter into regional trading agreements with the intention of facilitating bilateral trade. The dummy variable is equal to one when both countries in a given pair belong to the same regional group and 0 otherwise. The estimated coefficient will then tell us how much of the trade can be attributed to a special regional effect. On an average it has been found that FTAs impact positively on trade with a study by Frankel and Rose indicating a tripling of trade between partners on account of membership of RTAs. A list of the regional groups considered for our analysis with their member countries is presented in the Annex -Table III.

$U i j$ is a log-normally distributed error term and represents the myriad other influences on bilateral trade. $\mathrm{E}(\ln \mathrm{Uij})=0$.

\section{III.1 Methodology}

In the first stage we have estimated (equation 4) for world trade flows. Gravity model Equation (4) has been estimated using the OLS technique with cross - section data for the year 2000. The dependent variable is total merchandise trade (exports plus imports in US dollar thousands), in log form, between pairs of countries. All estimates are checked for heteroscedasticity. 
While panel data has advantages in terms of being able to capture the relevant relationships over time and panels monitor unobservable trading-partner-pairs' individual effects, classical gravity models have used cross-section data to estimate trade effects and trade relationship for a particular time period, which is invariably one particular year. Further gravity model has been estimated upto the year 1996 and it has been observed that aggregation over time does not really add any value to the estimations. We have therefore followed the classical tradition of estimation with cross-section data.

In the second stage the estimated coefficients from the first stage have been used to analyze India's trade pattern in general and with some regional groupings in particular. The latter have been selected keeping in mind the prospective preferential trading arrangements that are in offing in the near future or are already operational. The regional groupings that have been analyzed for trade potential with India are SAARC, ASEAN and GCC. India-China trade potential finds a special mention in view of the ongoing efforts for expansion of bilateral trade between the two countries.

\section{III.1.1 Econometric Issues}

\section{Multicollinearity:}

Klein's thumb rule as well as simple correlations have been used to test for multicollinearity ${ }^{2}$ in our specification. Simple correlations are small (refer AppendixTable 2) and the auxiliary regressions for Klein's rule do not indicate multicollinearity. Multicollinearity is thus not a problem in our specification of the gravity model.

\section{Endogeneity}

Both economic size and income per capita are treated as exogenous variables in the gravity equation. There is, however empirical and theoretical support for the impact that trade can have on income. The possibility of endogeneity of these variables therefore cannot be denied and the apparently significant effect of income on trade may be

2 According to Klein's rule of thumb, multicollinearity is a problem if $\max \mathrm{R}_{\mathrm{j}}{ }^{2}>\mathrm{R}^{2}$ where $\mathrm{R}_{\mathrm{j}}{ }^{2}$ is the statistic from the OLS estimation of the auxiliary regression of the $\mathrm{j}^{\text {th }}$ regressor on the other regressors and the intercept term. Several auxilliary regressions were estimated and this condition did not hold true for any of the regressors, as all $\mathrm{R}_{\mathrm{j}}^{2}$ were less than .2 . 
spurious. To resolve this problem we have attempted alternative instrumental variables (IV) estimations using instruments like population and land area for size ${ }^{3}$. The use of instrumental variable technique does not alter the coefficients on any of the variables to any significant extent ${ }^{4}$, implying thereby that the endogeneity of income does not lead to any significant distortion of the initially postulated relationship in the gravity model.

\section{Country Pairs with Zero data:}

For some country pairs the data entry is zero, normally due to levels of trade that are too small to be recorded. These are generally countries that, by virtue of their small size and remoteness, would be expected to have little trade with each other. It is not always possible, though, to ascertain whether their trade is actually zero or is very small and has in the process of being rounded off appeared as zero value. In any case, these pairs with zero trade values present a problem for estimation of the gravity model in the log linear form. We have tried to resolve this problem by estimating the model using three different techniques:

- Omission of the zero pairs from the data set

- Estimation of a restricted model, that is, estimate the gravity model for all countries that have income above US \$15 million ${ }^{5}$.

- A semi-log formulation of the gravity model. The reformulated gravity equation is then estimated using Tobit technique ${ }^{6}$.

No significant changes in coefficient values are however found.

\section{III.2 Data Sample}

The dependent variable in our analysis is the natural $\log$ of total bilateral trade (exports plus imports) measured in current international prices (dollar value). Our analysis is based on the maximum possible geographical coverage of world trade flows. Our data source is the PC TAS. PC TAS is derived from the trade database of the United

3 Correlation between population and GNP and land area and GNP is greater than .5, thereby indicating the strength of these variables as instruments for GNP/size.

$4 \quad$ Results are not reported here, but are available on request from the author.

5 Model IX -Results presented in Appendix- Table 3

6 Model XI and XII -Results presented in Appendix-Table 3 
Nation's Statistics Division, and covers over 90 per cent of world trade. 146 countries $^{7}$ report their exports and imports with trading partners drawn from a set of 245 countries. There are 20531 observations in the sample. Observations for all variables are for the year 2000 .

GNP is measured in current international prices (dollars) as well as in PPP terms. Population of all countries is measured in millions. The data source for population and GNP is the World Bank published World Development Indicators (CD-ROM, 2003).

Bilateral distance is measured, in kilometers, as the great circle distance between two capital cities of the trading partners. ${ }^{8}$ Bilateral distance is from the data set developed by Haveman ${ }^{9}$ and the CEPII ${ }^{10}$. For language, contiguity, colonial background and other such information we have used the CIA World Factbook.

As there are missing observations for some of the regressors, the usable sample may be much smaller for most estimations.

\section{Estimation Results}

Table 3 presents the OLS estimates of the basic and augmented gravity models ${ }^{11}$. We analyze the results of the augmented model for both GNP at current international US \$(Model VII) and in terms of PPP (Model IV).

Gravity model estimation results using GDP at current international dollar:

The model for both the basic and augmented version fits the data well and explains 70 per cent of the variation in bilateral trade across our sample of countries. The

\footnotetext{
A list of the sample countries is given in the Annex-Table-II.

8 Great circle distance is measured between any two latitude-longitude combinations-i.e. "as the crow flies" between two cities. Where distance between capital cities is not available, distance between major cities of the trading partners has been used.

9 www.macalester.edu/research/economics/PAGE/HAVEMAN/Trade.Resources/Data/Gravity/dist.txt 10 www.cepii.fr.

11 Some other variations of the gravity model that have been estimated are also reported with model descriptions in the Appendix.
} 
standard features of the gravity model work well. Distance and income provide most of the explanatory power in all the regressions. The baseline variables (both GDP and distance) are very highly significant, have the expected signs and are of reasonable magnitude.

The coefficient on the GNP variable in our specification is positive, statistically significant and economically reasonable indicating that higher GDP (for the country pairing) increases trade. Given that the coefficient is less than one (.87), an increase in the size of the country (output) increases trade, though, less than proportionately.

The estimated coefficient on log distance has the anticipated negative sign and is slightly over one, indicating that trade between a pair of countries falls by a little over 1 per cent for every 1 percent increase in the distance between them ${ }^{12}$. On controlling for adjacency, i.e. inclusion of the variable for common border, the magnitude of the coefficient on distance is reduced slightly. The coefficient on the dummy variable for a common border itself is estimated to be .56. As trade is specified in logarithmic form, we interpret the coefficient on the dummy by taking the exponent. Two countries that share a common border are estimated to engage in 75 per cent more trade than two otherwisesimilar countries.

We have also included an effect for landlockedness, which may add to transportation costs. The coefficient on the dummy for this effect is estimated at -0.26 . This implies that, holding constant for other factors, the lack of ocean ports reduces trade by about 30 per cent.

Sharing a language increases trade by economically and statistically significant amounts. The estimated coefficient of the common language dummy is .55. The implication is that two countries sharing linguistic links tend to trade roughly 74 per cent

12 When the adjacency variable is not included in the gravity equation, the estimated coefficient on the log distance is a little more than, when it is included. When we hold constant for common borders, the estimated coefficient on the distance variable is diminished by a very small magnitude. The adajcency variable is to be included however, as it has its own relevance, beyond distance, for bilateral trade. 
more than they would otherwise. The effect of sharing a common language though positive, is not as much as the effect of sharing a common border.

Ex-colonies and their colonizers and countries with the same colonizer all have disproportionately intense trade, consistent with intuition and received wisdom. Coefficients on the dummy variables representing these effects are positive and significant.

\section{Effects of RTAs:}

We find that the dummy variable for intra-regional trade is highly significant statistically. The common membership of a RTA explains some amount of bilateral trade over and above that explained by the five basic variables - size, per capita income, bilateral distance, common borders, and common languages. The coefficient on the dummy variable for regional trading arrangements is .87 , implying that the preferential trading arrangements can lead to over twice as much trade as is otherwise possible for a country pair $^{13}$. However the regional dummy when dis-aggregated into individual RTA dummies does not seem to have the same impact. This is even more apparent when we separate out the trade creating and trade diversion effects of these preferential trading arrangements. Specifically when we consider the Bangkok Agreement (BA) and the SAARC PTA in our specification, the trade diversion effects of the latter stand out for being highly significant in comparison with the trade creation effects. In case of the BA, while substantial trade creation is possible, the estimates also show the arrangement to be more open vis a vis the rest of the world (Refer Appendix-Table 3).

\section{Gravity Model estimation results using GNP at PPP}

The results reported above are for GNP and per capita GNP at current exchange rates. Alternatively these variables are measured at purchasing power parity rates (PPP). In theory the PPP rates are preferable as large temporary swings in the nominal exchange rate can distort the comparison of incomes across countries. The usual disadvantage cited against measurement of PPP values is that they may be subject to large measurement

\footnotetext{
${ }^{13}$ The dummy for RTA in the gravity equation does not distinguish between trade creating and trade diversion effects. The impact as indicated by the estiamted coefficient for the dummy therefore should be taken as the upper bound on trade creation effects of the RTA.
} 
errors. Considering, however, that India's income is significantly understated in current dollar terms, we estimate the gravity model using the PPP measure also.

Most of the coefficients are left largely unaffected in terms of sign and significance. The coefficient for GNP per capita was statistically significant and positive. This was in contrast with the model with income measured at the current exchange rate. In that case per capita income was insignificant and was later dropped on account of high multi-collinearity. (Refer Appendix - Table 2)

\section{Linder vs. Hecksher-Ohlin hypothesis:}

To test for the strength of the Linder hypothesis as against the H-O hypothesis we have included the log of absolute difference in GNP per capita for a country pair. As stated earlier this allows us to address the question-whether trade flows are large among similar countries or dissimilar countries. Our estimation results support the Linder hypothesis. Similar countries trade more than dissimilar ones. The log difference of PC incomes appears as negative and significant for the model with these variables expressed in current international dollars. In case of the PPP model the negative sign is retained even though the variable does not remain significant. The coefficient on the product of per capita incomes remains positive however, and is highly significant. This suggests that the trade and development relationship is the most powerful of all the three channels through which per capita income can impact upon trade.

\section{India's Trade Potential}

Having estimated the gravity model for bilateral trade flows in the world, we proceed to estimate trade potential for India. In this section the model estimates from the previous section are used to predict India's trade with all the countries in our sample. The ratio of trade potential $(\mathrm{P})$ as predicted by the model and actual trade (A) i.e. (P/A) is then used to analyze the future direction of trade for India. If the value of P/A exceeds one, the implication is in terms of potential expansion of trade with the respective country. Depending on the value of P/A, India's trading partners have been divided into two categories-those with which potential for expansion of trade is foreseen and countries 
with which India has already exceeded its trade potential. The absolute difference between the potential and actual level of trade i.e. the value of (P-A) has also been used to classify countries with potential for expansion of trade with India. A positive value indicates future possibilities of trade expansion while a negative value shows India has exceeded its trade potential with the particular partner country ${ }^{14}$.

The magnitude of India's trade potential is maximum with countries like China, United Kingdom, Pakistan, Japan, Italy and France. Our estimates indicate that India can potentially attain ten times or more trade with countries like Georgia, Turkmenistan, and Uzbekistan. With countries like Lithuania, Tajikistan, Mongolia, Romania, Luxembourg and Norway, potential trade as predicted by our model is five times or more than the actual level of trade. Potential trade, that is more than twice the level of actual trade, is indicated for countries like China, Japan, Austria, Mexico, Qatar etc.

\section{V.1 Regional Distribution of India's Trade Potential ${ }^{15}$}

When India's trade potential is compared across different regions of the world, maximum potential is indicated for the Asia - Pacific region followed by western Europe, North America, Middle East, Central and Eastern Europe and Latin America. In Asia, Japan, Pakistan, China, Philippines and Korea reveal maximum potential for expansion of trade with India. Among the set of countries comprising the EU, India has trade potential with all except Belgium. In North America both the US and Canada reveal considerable potential for expanding trade. In Central and Eastern Europe, Poland, has the maximum potential for expansion of trade with India.

Most of the countries in the CIS region reveal possibilities of expanding trade with India. However, for the region as a whole, our findings show that India has exceeded its trade potential. This can be explained by the large magnitude of trade that India has with the Russian Federation. Russian Federation along with Ukraine and Belarus

\footnotetext{
${ }^{14}$ Refer Appendix -Table 4 (A-F) for countries with potential for expansion of trade with India. Refer Appendix - Table 5 (A-D) for countries where India has exceeded its trade potential.
} 
constitute the group of countries in the CIS region, with which India has exceeded its trade potential.

\section{V.2 India's Trade Potential with Regional Groupings in Asia ${ }^{16}$}

In the paragraphs that follow we analyze India's trade potential with a set of countries defined by some preferential trading arrangements that are already operational or in offing in the near future using the estimates obtained from the model. In particular, we consider the group of countries constituting SAARC, ASEAN and the GCC. India's total trade with both SAARC and ASEAN has been increasing and the increase was 25 per cent in the period 2001-2002 -2002-2003. Currently the share of SAARC and ASEAN in total trade for India is small, about 8-9 per cent.

\section{V.2.1 India-SAARC}

\begin{tabular}{|l|}
\hline Pakistan $^{1}$ \\
\hline Maldives $^{1}$ \\
\hline Nepal $^{1}$ \\
\hline Sri lanka $^{3}$ \\
\hline Bangladesh $^{2}$ \\
\hline Bhutan $^{2}$ \\
\hline \\
\hline
\end{tabular}

1- potential, 2- no data available, 3- overtraded

Among the SAARC nations high trade potential according to both P/A as well as the magnitude of potential is indicated for Pakistan. In fact, among all SAARC member nations India's trade potential is indicated only for Pakistan. P/A ratio for Pakistan is very high. The magnitude of trade potential with India-Pakistan trade has thus far been restricted on account of political barriers and at present (2002-03) it accounts for only about 8 per cent of India's total trade with SAARC. In comparison Bangladesh, Sri Lanka and Nepal accounted for 38, 32 and 20 per cent respectively in the same period. For both Sri Lanka and Nepal our model yields a P/A ratio that is less than one indicating that

\footnotetext{
${ }^{15}$ Countries ranked according to the ratio of India's trade potential to actual trade and magnitude of trade potential in different regions is presented in the Appendix-Table 4(C and F).

16 In the respective groupings, countries ranked according to the ratio of India's potential to actual trade and magnitude of difference between potential and actual trade is presented in the Appendix-Table 6(A and B).
} 
India has gone far beyond the level of trade predicted on the basis of natural factors with these two countries.

\section{V.2.2 India-ASEAN}

\begin{tabular}{|l|}
\hline Philippines $^{1}$ \\
\hline Cambodia $^{1}$ \\
\hline Vietnam $^{1}$ \\
\hline Thailand $^{3}$ \\
\hline Indonesia $^{3}$ \\
\hline Malaysia $^{3}$ \\
\hline Singapore $^{3}$ \\
\hline Laos $^{2}$ \\
\hline Myanmar $^{2}$ \\
\hline Brunei $^{2}$ \\
\hline
\end{tabular}

1- potential, 2- no data available, 3- overtraded

Among the ASEAN nations high trade potential is indicated for Philippines, Vietnam and Cambodia. At present Philippines has the lowest share in India's total trade with ASEAN. Philippines accounts for only six per cent of India's total trade with ASEAN in comparison with over 20 per cent share of countries like Singapore, Malaysia and Indonesia. Thailand also accounts for 11 per cent of India's trade with ASEAN. Our results indicate possibility of trade potential with Thailand, only with estimates of the model with GNPP at PPP. The value of the P/A ratio indicates that India has attained its potential with Vietnam. With countries like Malaysia, Indonesia and Singapore India seems to have exceeded its Trade potential.

\section{V.2.3 India-GCC}

\begin{tabular}{|l|}
\hline Oman $^{1}$ \\
\hline Qatar $^{1}$ \\
\hline Kuwait $^{1}$ \\
\hline Bahrain $^{3}$ \\
\hline Saudi Arabia $^{3}$ \\
\hline UAE $^{2}$ \\
\hline
\end{tabular}

1- potential, 2- no data available, 3-overtraded 
Among the countries of the Gulf Cooperation Council, our model estimates yield a high trade potential for Oman, Kuwait and Qatar. With Oman, trade can be thrice as much as the actual trade while with Qatar the level of trade can be doubled. At present UAE ranks the highest and is followed by Saudi Arabia in terms of India's total trade with the GCC countries. For Saudi Arabia our model indicates a P/A ratio of less than one. This indicates that India's trade with Saudi Arabia has already crossed its potential.

\section{V.2.4 India-China}

Trade between India and China has been increasing in the recent years. Total trade increased by almost 46 per cent in 2003-04 over the previous year. However there is vast potential for expansion in India-China bilateral trade. The natural links between India and China, common border and their geographical proximity open vast opportunities for bilateral trade. The gravity model, when estimated with current GNP values in US \$ yields a value of trade potential that is 2.5 times the actual trade between India and China.

Trade possibilities between India and China are further enhanced by access to an enlarged market owing to common membership of the Bangkok Agreement. China acceded to the Bangkok Agreement in 2001. The Bangkok Agreement is the largest PTA in terms of market potential. The size of the market and proximity of the two economies are thus indicative of a huge potential for trade between India and China.

\section{Conclusions}

In this paper we have estimated the trade potential for India using the augmented gravity model. Cross section data for the year 2000 has been analyzed using OLS estimation technique. Our analysis is based on maximum possible coverage of world trade flows.

The gravity equation fits the data and delivers precise and plausible income and distance elasticities and estimates for other geographical and historical characteristics. All 
three of the traditional "gravity" effects are intuitively reasonable, with statistically significant t-statistic, often exceeding 50 in absolute value. As per received wisdom and intuition, higher economic size of a country pair and geographical proximity positively influence bilateral trade flows. Alternative measures of GNP in terms of current dollar value and purchasing power parity do not alter either the sign or significance of different explanatory variables. Historical and cultural similarities also impact positively upon bilateral trade.

Our estimates of India's global trade potential reveal that the magnitude of India's trade potential is maximum in the Asia-Pacific region followed by Western Europe and North America. Potential for expansion of trade is highest with countries like China, United Kingdom, Italy and France. Our estimates indicate that India can potentially attain ten times or more the level of the actual trade with countries like Georgia, Turkmenistan, and Uzbekistan. In fact, most of the countries in the CIS region reveal possibilities of expanding trade with India. For the region as a whole, however, our estimates show that India has exceeded its trade potential. This may be explained by the large magnitude of trade that India has with the Russian Federation. Among specific country groupings/trade arrangements India's trade potential is maximum with Pakistan in SAARC, with Philippines and Cambodia in the ASEAN region and with Oman, Qatar and Kuwait in the GCC. 


\section{References}

Anderson, James.E and Eric van Wincoop (2001) " Borders, Trade and Welfare", Working paper 8515, National Bureau of Economic Research

Anderson, James.E and Eric van Wincoop (2001) "Gravity with Gravitas; A Solution to the Border Puzzle”, Working paper 8079, National Bureau of Economic Research.

Benedictis, Luca De and Caludio Vicarelli (2004) "Trade Potentials in Gravity Panel Data Models".

Bergstrand, Jeffrey H. (1985) "The gravity Equation in International Trade: Some Microeconomic Foundations and Empirical Evidence". Review of Economics and Statistics 71, no. 1 .

Carrillo, Carlos and Carmen A Li (2002) "Trade Blocks and the Gravity Model: Evidence from Latin American Countries", University of Essex, UK.

Cheng, Hui-I and Howard J. Wall (2003)“ Controlling Heterogeneity in Gravity Models of Trade and Integration”, Working paper 1999-010D, Federal Reserve Bank of St. Louis.

Christie, Edward (2002) "Potential Trade in Southeast Europe: A Gravity Model Approach", WIIW Working Paper No. 21.

Deardorff, Alan (1995) "Determinants of Bilateral Trade: Does Gravity Work in a Classical World?", paper presented at conference on The Regionalization of the World Economy, NBER, Woodstock, Vermont.

Feenstra, Robert C, James A.Markusen and Andrew.K.Rose (1999) "Using The Gravity Equation to Differentiate Among Alternative Theories of Trade", http://www.econ.ucdavis.edu/feenstra.

Frankel, Jeffrey A (1993) “Trade Blocs and Currency Blocs”, Working Paper No. 4335, National Bureau of Economic Research.

Frankel, Jeffrey A (1997) “ Regional Trading Blocs”, Institute for International Economics.

Frankel, Jeffrey and Shang-Jin Wei (1993) “Trade Blocs and Currency Blocs", Working Paper No. 4335, NBER, Cambridge, MA.

Frankel, Jeffrey and Andrew Rose "An Estimate of the Effect of Common Currencies on Trade and Income?", The Quarterly Journal of Economics (May 2002), pp. 437-466. 
Frankel, Jeffrey amd David Romer (1996) “Trade and Growth”, NBER Working Paper No. 5476, National Bureau of Economic Research.

Frankel, Jeffery and Andrew Rose (August 2000) "Estimating the Effect of Currency Unions on Trade and Output", Working Paper No. 7857, National Bureau of Economic Research.

Frankel, Jeffrey, Ernesto Stein and Shang-jin Wei (1995) "Trading Blocs and the Americas: The natural, the unnatural, and the super-natural. Journal of Development Economics

Ghosh, Sucharita and Steven Yamarik (2002) "Are Regional Trading Arrangements Trade Creating? An Application of Extreme Bounds Analysis".

Harris, Mark N and Lázlo Mátyás (1998) “ The Econometrics of Gravity Models”, Working Paper No. 5/98, Melbourne Institute of Applied Economic and Social Research.

Head Keith (2003) "Gravity for Beginners", University of British Columbia, Vancouver.

Helpman, Elhanan (1987) "Imperfect Competition and International Trade:Evidence from Fourteen Industrial Countries", Journal of the Japanese and International Economics, 1 (March), pp. 62-81.

Helpman, Elhanan and Paul R. Krugman (1985) " Market Structure and Foreign Trade: Increasing Returns, Imperfect competition, and the International Economy”, Cambridge: MIT Press.

International Trade Centre (UNCTAD/WTO) (2003) "TradeSim (second version), A gravity model for the calculation of trade potentials for developing countries and economies in Transition", Explanatory notes, Market Analysis Section.

Kalbasi, Dr. Hassan (2001) “ The Gravity Model and Global Trade Flows”, Paper in the Conference of EcoMod, Washington DC.

Leamer, Edward.E " Let's Take the Con Out of Econometrics", The American Economic Review, Volume 73, No.1 (1983), pp. 31-43.

Leamer, Edward.E "Sensitivity Analysis Would Help”, The American Economic Review, Volume 75, No.3 (1985), pp. 308-313.

Linnemann, Hans (1966) "An Econometric Study of International Trade Flows", Amsterdam, North Holland.

Noguer, Marta and Marc Siscart (2003) “Language as a Barrier to International Trade? An Empirical Investigation". 
Okubo, Toshihiro (2003) “ The Border Effect in the Japanese Market: A Gravity Model Analysis", Discussion Paper No. 494, University of Michigan, http://www.spp.umich.edu/rsie/workingpapers/wp.html.

Porojan, A (2000) "Trade Flows and Spatial Effects: The Gravity Model Revisited", University of Derby.

Poyhonen, Pentti, (1963) "A Tentative Model for the Volume of Trade Between Countries", Weltwirtschaftliches Archiv 90.

Rahman, Mohammad Mafizur (2003) “A Panel Data Analysis of Bangladesh's Trade: The Gravity Model Approach”. University of Sydney.

Rauch, James.E (1996) "Networks Versus Markets in International Trade", Working Paper 5617, National Bureau of Economic Research.

Rose, Andrew.K (2000) "EMU's Potential Effect on British Trade: A Quantitative Assessment", University of California, Berkley.

Rose, Andrew.K (2000) "One Money, One Market: Estimating the Effect of Common Currencies on Trade", University of California, Berkley.

Sachs, Jeffrey.D and Andrew.M. Warner (1995)“ Natural Resource Abundance and Economic Growth”, Working Paper 5398, National Bureau of Economic Research.

Smith, Christie (2002) "Currency Unions and Gravity Models Revisited", Discussion Paper Series, Reserve Bank of New Zealand.

Tinbergen Jan (1962), "An Analysis of World Trade Flows: in Shaping the World Economy, ed. by Jan Tinbergen, New York, The Twentieth Century Fund.

Yamarik, Steven and Sucharita Ghosh (2002) "A Sensitivity Analysis of the Gravity Model".

Yevati, Eduardo Levy (2001) “ On the Impact of a Common Currency on Bilateral Trade". Universidad Torcuato Di Tella. 


\section{Appendix}

Table 1: Descriptive Statistics

\begin{tabular}{|l|c|c|c|c|c|}
\hline & Obs. & Mean & Std.Dev & Min & Max \\
\hline Trade & 7249 & 863847.3 & 7695192 & 1 & $3.96 \mathrm{e}+08$ \\
\hline Trmfg & 5611 & 84469.6 & 6651419 & 4 & $2.54 \mathrm{e}+08$ \\
\hline gdp1 & 20803 & $3.02 \mathrm{e}+11$ & $9.06 \mathrm{e}+11$ & $4.17 \mathrm{e}+08$ & $9.58 \mathrm{e}+12$ \\
\hline gdpc1 & 20972 & $2.04 \mathrm{e}+11$ & $8.18 \mathrm{e}+11$ & $4.3 \mathrm{e}+07$ & $9.81 \mathrm{e}+12$ \\
\hline pc1 & 20803 & 9507.19 & 9349.66 & 450 & 53410 \\
\hline cpc1 & 20972 & 6943.04 & 9528.98 & 95.27 & 43043.24 \\
\hline dist & 20291 & 8111.32 & 4622.63 & 4.01 & 131866.8 \\
\hline area1 & 21294 & 861593.7 & 2152450 & 300 & $1.69 \mathrm{e}+07$ \\
\hline pop1 (mn) & 22231 & $4.03 \mathrm{e}+07$ & $1.49 \mathrm{e}+08$ & 44000 & $1.26 \mathrm{e}+09$ \\
\hline dl & 22603 & .08 & .27 & 0 & 1 \\
\hline dcomcol & 22603 & .03 & .18 & 0 & 1 \\
\hline dlandlock & 22603 & .36 & .55 & 0 & 2 \\
\hline dborder & 22603 & .01 & .10 & 0 & 1 \\
\hline disland & 22603 & .50 & .61 & 0 & 2 \\
\hline dcomctry & 22603 & .00 & .04 & 0 & 1 \\
\hline dcolonial & 22603 & .00 & .06 & 0 & 1 \\
\hline dregnl & 22603 & .01 & .10 & 0 & 1 \\
\hline
\end{tabular}

Table 2: Simple Correlations

\begin{tabular}{|c|c|c|c|c|c|c|c|c|c|c|c|c|c|c|c|c|}
\hline & trade & area1 & Pop1 & gdp1 & pc1 & dist & dl & dcomcol & Dlandlock & dborder & disland & dcomctry & dcolonial & dregnl & cpc1 & trmfg \\
\hline trade & 1 & & & & & & & & & & & & & & & \\
\hline area1 & 0.04 & 1 & & & & & & & & & & & & & & \\
\hline pop1 & 0.04 & 0.48 & 1 & & & & & & & & & & & & & \\
\hline gdp1 & 0.08 & 0.51 & 0.63 & 1 & & & & & & & & & & & & \\
\hline pc1 & 0.07 & 0.01 & -0.23 & 0.21 & 1 & & & & & & & & & & & \\
\hline dist & -0.06 & 0.2 & 0.09 & 0.14 & 0.03 & 1 & & & & & & & & & & \\
\hline dl & 0.03 & 0.04 & -0.02 & 0.02 & -0.06 & -0.10 & 1 & & & & & & & & & \\
\hline dcomcol & \begin{tabular}{|l|}
-0.02 \\
\end{tabular} & -0.06 & 0.03 & -0.05 & -0.11 & -0.08 & 0.25 & 1 & & & & & & & & \\
\hline dlandlock & -0.05 & -0.10 & -0.07 & -0.09 & -0.01 & -0.16 & -0.10 & -0.06 & 1 & & & & & & & \\
\hline dborder & 0.17 & 0.02 & 0.04 & 0.00 & -0.09 & -0.20 & 0.15 & 0.08 & 0.02 & 1 & & & & & & \\
\hline disland & 0.01 & 0.00 & -0.06 & 0.05 & 0.20 & 0.19 & 0.17 & 0.10 & -0.22 & -0.09 & 1 & & & & & \\
\hline dcomctry & 0.01 & 0.00 & 0.02 & 0.03 & 0.05 & 0.00 & 0.13 & -0.01 & -0.03 & -0.01 & 0.10 & 1 & & & & \\
\hline dcolonial & 0.00 & -0.04 & -0.02 & 0.00 & 0.02 & -0.01 & 0.22 & -0.02 & -0.03 & -0.02 & 0.12 & 0.11 & 1 & & & \\
\hline dregnl & 0.14 & -0.05 & -0.04 & -0.04 & 0.06 & -0.16 & 0.17 & 0.14 & -0.05 & 0.15 & 0.14 & 0.01 & 0.01 & 1 & & \\
\hline cpc1 & 0.08 & 0.00 & -0.18 & 0.28 & 0.95 & 0.06 & -0.05 & -0.10 & -0.04 & -0.08 & 0.23 & 0.05 & 0.03 & 0.06 & 1 & \\
\hline trmfg & 0.98 & 0.03 & 0.04 & 0.08 & 0.07 & -0.06 & 0.02 & -0.02 & -0.05 & 0.16 & 0.01 & 0.02 & 0.00 & 0.14 & 0.08 & 1 \\
\hline
\end{tabular}


Table 3: Gravity Model Estimates

\section{Dependent Variable: Log (trade between country pairs)}

\begin{tabular}{|c|c|c|c|c|c|c|c|c|c|c|}
\hline \multicolumn{5}{|c|}{ GNP-PPP } & \multicolumn{6}{|c|}{ GNP-Current US\$ } \\
\hline Var/model & I & II & $\mid \mathrm{III}(\mathrm{L} / \mathrm{H}-\mathrm{O})$ & IV & $\mathbf{V}$ & VI & VII & VIII & IX: $:<15$ & \begin{tabular}{|l}
$\mathrm{X}(\mathrm{Li} / \mathrm{HO})$ \\
\end{tabular} \\
\hline PGNP & 0.92 & 0.84 & \begin{tabular}{|l|}
0.86 \\
\end{tabular} & 0.86 & 0.87 & 0.87 & 0.87 & 0.92 & 0.87 & 0.89 \\
\hline Dist. & -1.16 & -1.11 & -1.04 & -1.04 & -1.17 & -1.17 & -1.11 & -1.09 & -1.11 & -1.11 \\
\hline PGNPPC & & 0.39 & .38 & 0.38 & & $0.006^{*}$ & & & & \\
\hline Border & & & 0.71 & 0.72 & & & 0.56 & 0.40 & 0.56 & 0.46 \\
\hline Language & & & 0.72 & 0.72 & & & 0.55 & 0.77 & 0.55 & 0.54 \\
\hline Comcol & & & 0.61 & 0.61 & & & 0.51 & 0.31 & 0.51 & 0.48 \\
\hline Col & & & 1.24 & 1.23 & & & 1.0 & 0.89 & 1.0 & 1.05 \\
\hline Comctry & & & 1.37 & 1.39 & & & 1.53 & - & 1.53 & 1.56 \\
\hline Landlocked & & & -0.45 & -0.45 & & & -0.26 & $0.01 *$ & -0.26 & -0.24 \\
\hline Island & & & 0.07 & 0.07 & & & 0.09 & 0.08 & 0.09 & 0.13 \\
\hline Regl. & & & 1.11 & 1.12 & & & 0.87 & 0.55 & 0.87 & 0.84 \\
\hline crude1 & & & - & - & & & & -0.01 & & \\
\hline crude 2 & & & - & - & & & & -0.01 & & \\
\hline LPC & & & $-0.02 *$ & & & & & & & -0.07 \\
\hline Int. & -26.57 & -29.9 & -31.12 & -31.17 & -22.43 & -22.4 & -23.18 & -25.34 & -23.18 & -23.29 \\
\hline Adjusted $\mathrm{R}^{2}$ & .63 & .67 & .70 & .70 & .69 & & .71 & .73 & .73 & .71 \\
\hline No. of Obs. & 5801 & 5801 & 5798 & 5801 & 5986 & 5986 & 5986 & 2422 & 5986 & 5986 \\
\hline
\end{tabular}

Tobit Models

RTA Effects

\begin{tabular}{|l|c|c|c|c|}
\hline Var/model & XI(PPP) & XII (Current) & BA & SAPTA \\
\hline PGNP & .86 & .87 & .87 & .86 \\
\hline Dist. & -1.04 & -1.11 & -1.08 & -1.04 \\
\hline PGNPPC & .38 & - & & \\
\hline Border & .72 & .56 & .33 & .38 \\
\hline Language & .72 & .55 & .52 & .47 \\
\hline Comcol & .61 & .51 & .34 & .44 \\
\hline Col & 1.23 & 1.0 & .92 & .86 \\
\hline Comctry & 1.39 & 1.53 & 1.67 & 1.85 \\
\hline Landloc. & -.45 & -.26 & -.08 & -08 \\
\hline Island & .07 & .09 & .02 & .04 \\
\hline Regl. $^{\text {band }}$ & 1.12 & .87 & .87 & .85 \\
\hline ba & & & .61 & \\
\hline ba & & & .86 & \\
\hline SAPTA $_{\mathrm{I}}$ & & & & -.17 \\
\hline SAPTA $_{i j}$ & & & & .30 \\
\hline Int. & -31.17 & -23.18 & -23.41 & -24.12 \\
\hline No. of Obs. & 5801 & 5988 & 4796 & 4796 \\
\hline
\end{tabular}

All variables except dummies are in logs

All results are checked for heteroscedasticity

*: not significant

LPC $=\log$ of the absolute difference in per capita incomes of country 1 and 2 in the bilateral pair.

$\mathrm{PGNP}=\log (\mathrm{Y} 1 * \mathrm{Y} 2)$

$\mathrm{PGNPPC}=\log \left(\mathrm{Y}_{1} / \mathrm{pop}_{1} * \mathrm{Y}_{2} / \mathrm{pop}_{2}\right)$ 


\section{Model Description}

I. $\quad \log \left(\right.$ Trade $\left._{\mathrm{ij}}\right)=\alpha+\beta_{1} \log \left(\mathrm{GNP}_{\mathrm{i}} \cdot \mathrm{GNP}_{\mathrm{j}}\right)+\beta_{2} \log \left(\right.$ distance $\left._{\mathrm{ij}}\right)+\mathrm{u}_{\mathrm{ij}}$

II. $\log \left(\right.$ Trade $\left._{\mathrm{ij}}\right)=\alpha+\beta_{1} \log \left(\mathrm{GNP}_{\mathrm{i}} \cdot \mathrm{GNP}_{\mathrm{j}}\right)+\beta_{2} \log \left(\right.$ distance $\left._{\mathrm{ij}}\right)+\log ($ PciPcj $)+\mathrm{u}_{\mathrm{ij}}$

III. IV with PC entered as absolute value of the difference of log per capita incomes

IV. II + All dummies

Models I to IV are estimated using GNP in terms of PPP.

V. I with GNP in current US \$

VI. II with GNP in current US \$

VII. VI + All Dummies**

VIII. VII+ Crude Oil Reserves ${ }^{1}$

IX. VIII for all reporter countries with GNP > 15 million

X. VII with PC income variable entered to test for Linder/H-O hypothesis

XI. Semi-log (Tobit) estimation of VII

XII. Semi-log (Tobit) estimation of IV

*: Alternative model:

II': $\log \left(\operatorname{Trade}_{\mathrm{ij}}\right)=\alpha+\beta_{1} \log \left(\mathrm{GNP}_{\mathrm{i}} \cdot \mathrm{GNP}_{\mathrm{j}}\right)+\beta_{2} \log \left(\right.$ distance $\left._{\mathrm{ij}}\right)+\log ($ PopiPopj $)+\mathrm{u}_{\mathrm{ij}}$

** The variable for per capita income is dropped in this and all the subsequent models using current GNP figures.

${ }^{1}$ To account for natural resources of individual countries. 


\section{India's Trade Potential}

Note:

For all Tables below:

p- trade potential using estimates of the augmented gravity model; a-actual trade;

ppp: trade potential indicates estimates using model IV(GNP at PPP)

c- trade potential indicates estimates using model VII(GNP at current exchange rate)

Countries where India has already attained its potential have not been included.

Table 4A:Countries with Potential for Expansion of Trade (P/A) $)_{p p p}$

\begin{tabular}{|c|c|c|c|}
\hline Country & $(\mathbf{P} / \mathbf{A})_{\mathrm{ppp}}$ & Country & $(\mathbf{P} / \mathbf{A})_{\mathrm{ppp}}$ \\
\hline Bosnia and Herzegovina & 3302.1 & Hungary & 3.2 \\
\hline Macao, China & 77.7 & Turkey & 3.2 \\
\hline Pakistan & 52.2 & Guyana & 3.1 \\
\hline Macedonia,TFYR & 25.9 & Belarus & 2.9 \\
\hline Turkmenistan & 25.7 & Portugal & 2.9 \\
\hline Georgia & 22.8 & \begin{tabular}{|l|} 
Uganda \\
\end{tabular} & 2.9 \\
\hline New Caledonia & 17.3 & Mexico & 2.7 \\
\hline Uzbekistan & 13.9 & Austria & 2.5 \\
\hline El Salvador & 12.5 & Canada & 2.5 \\
\hline Lithuania & 11.2 & Japan & 2.5 \\
\hline Malta & 11.2 & Peru & 2.5 \\
\hline Papua New Guinea & 10.7 & Ukraine & 2.5 \\
\hline Romania & 10.7 & Sudan & 2.4 \\
\hline Tajikistan & 9.4 & Spain & 2.3 \\
\hline Slovakia & 9.2 & Bolivia & 2.2 \\
\hline Luxembourg & 9.1 & Denmark & 2.2 \\
\hline Namibia & 8.0 & Samoa & 2.2 \\
\hline Zaire & 8.0 & Syrian Arab Republic & 2.2 \\
\hline Bulgaria & 7.9 & Venezuela & 2.2 \\
\hline Cambodia & 7.9 & Czechoslovakia & 2.1 \\
\hline Mongolia & 7.8 & Kuwait & 2.1 \\
\hline Poland & 7.8 & Paraguay & 2.1 \\
\hline Cyprus & 7.3 & Solomon.Islands & 2.1 \\
\hline China & 6.5 & Suriname & 2.1 \\
\hline Azerbaijan & 6.2 & Italy & 2.0 \\
\hline Guatemala & 6.2 & Sweden & 2.0 \\
\hline Iceland & 6.0 & Vietnam & 2.0 \\
\hline Central African Republic & 5.8 & Brazil & 1.9 \\
\hline Croatia & 5.8 & Thailand & 1.9 \\
\hline Zimbabwe & 5.8 & USA & 1.9 \\
\hline Ireland & 5.5 & Korea, Rep. & 1.8 \\
\hline Philippines & 5.5 & Madagascar & 1.8 \\
\hline Gambia & 5.4 & Russian Fed & 1.8 \\
\hline Norway & 5.3 & Botswana & 1.7 \\
\hline Algeria & 5.1 & Malawi & 1.7 \\
\hline Kazakhstan & 5.1 & Finland & 1.6 \\
\hline United Kingdom & 4.9 & France & 1.6 \\
\hline Jamaica & 4.8 & Guinea & 1.6 \\
\hline Greece & 4.6 & Sierra.Leone & 1.6 \\
\hline Oman & 4.4 & Hong.Kong & 1.5 \\
\hline Cameroon & 4.2 & Lebanon & 1.4 \\
\hline Ecuador & 4.1 & Australia & 1.3 \\
\hline Estonia & 4.1 & Bahrain & 1.3 \\
\hline $\begin{array}{l}\text { Iran } \\
\end{array}$ & 4.1 & Germany & 1.3 \\
\hline Slovenia & 4.0 & Nepal & 1.3 \\
\hline Colombia & 3.8 & Kenya & 1.2 \\
\hline Costa Rica & 3.8 & South.Africa & 1.2 \\
\hline Latvia & 3.7 & Tunisia & 1.2 \\
\hline Kyrgyzstan & 3.6 & Netherlands & 1.1 \\
\hline New Zealand & 3.6 & Saudi Arabia & 1.1 \\
\hline Ghana & 3.3 & & \\
\hline
\end{tabular}


Table 4B: Countries with Potential for Expansion of Trade (P/A)c

\begin{tabular}{|c|c|c|c|}
\hline Country & $(\mathbf{P} / \mathbf{A})_{c}$ & Country & $(\mathbf{P} / \mathbf{A})_{c}$ \\
\hline Macao, China & 43.7 & Turkey & 2.3 \\
\hline Bosnia and Herzegovina & 43.4 & Algeria & 2.2 \\
\hline Pakistan & 26.7 & Kazakhstan & 2.2 \\
\hline Turkmenistan & 13.9 & Bolivia & 2.1 \\
\hline Macedonia,TFYR & 12.6 & Latvia & 2.1 \\
\hline Georgia & 11.9 & Mexico & 2.1 \\
\hline Uzbekistan & 9.5 & Slovenia & 2.1 \\
\hline Libya & 7.8 & Austria & 2.0 \\
\hline New Caledonia & 7.4 & Qatar & 2.0 \\
\hline El Salvador & 7.0 & Estonia & 1.9 \\
\hline Lithuania & 5.9 & Iran & 1.9 \\
\hline Mongolia & 5.5 & Lebanon & 1.9 \\
\hline Tajikistan & 5.5 & Madagascar & 1.8 \\
\hline Malta & 5.4 & Costa Rica & 1.7 \\
\hline Romania & 5.2 & Hungary & 1.7 \\
\hline Luxembourg & 5.0 & New Zealand & 1.7 \\
\hline Norway & 4.5 & Peru & 1.7 \\
\hline Papua New Guinea & 4.5 & Suriname & 1.7 \\
\hline Iceland & 4.3 & Sweden & 1.7 \\
\hline Poland & 4.2 & Denmark & 1.6 \\
\hline Slovakia & 4.1 & Kuwait & 1.6 \\
\hline Yugoslavia & 4.1 & Portugal & 1.6 \\
\hline Azerbaijan & 3.7 & Gambia & 1.5 \\
\hline Central African Republic & 3.7 & Seychelles & 1.5 \\
\hline Zaire & 3.7 & Colombia & 1.4 \\
\hline Croatia & 3.5 & Spain & 1.4 \\
\hline Guatemala & 3.5 & Syrian Arab Republic & 1.4 \\
\hline Cambodia & 3.3 & Canada & 1.3 \\
\hline Cyprus & 3.3 & Italy & 1.3 \\
\hline Cameroon & 3.1 & Sierra.Leone & 1.3 \\
\hline Namibia & 3.0 & Uganda & 1.3 \\
\hline Oman & 3.0 & Finland & 1.2 \\
\hline Japan & 2.9 & France & 1.2 \\
\hline Bulgaria & 2.8 & Korea, Rep. & 1.2 \\
\hline Greece & 2.8 & Malawi & 1.2 \\
\hline Ireland & 2.8 & Botswana & 1.1 \\
\hline United Kingdom & 2.7 & Brazil & 1.1 \\
\hline China & 2.6 & Kyrgyzstan & 1.1 \\
\hline Venezuela & 2.5 & USA & 1.1 \\
\hline Zimbabwe & 2.5 & & \\
\hline Ecuador & 2.4 & & \\
\hline Philippines & 2.3 & & \\
\hline
\end{tabular}


Table 4C:

Regional Distribution of Countries with Potential for Expansion of Trade* (P/A)

\begin{tabular}{|c|c|c|c|c|c|}
\hline Country & $(\mathbf{P} / \mathbf{A})_{\mathrm{ppp}}$ & $(\mathbf{P} / \mathbf{A})_{\mathrm{c}}$ & Country & $(\mathbf{P} / \mathbf{A})_{\mathrm{ppp}}$ & $(\mathbf{P} / \mathbf{A})_{\mathrm{c}}$ \\
\hline Latin America & & & CIS & & \\
\hline El Salvador & 12.5 & 7.0 & Turkmenistan & 25.7 & 13.9 \\
\hline Guatemala & 6.2 & 3.5 & Georgia & 22.8 & 11.9 \\
\hline Venezuela & 2.2 & 2.5 & Uzbekistan & 13.9 & 9.5 \\
\hline Ecuador & 4.1 & 2.4 & Tajikistan & 9.4 & 5.5 \\
\hline Bolivia & 2.2 & 2.1 & Azerbaijan & 6.2 & 3.7 \\
\hline Mexico & 2.7 & 2.1 & Kazakhstan & 5.1 & 2.2 \\
\hline $\begin{array}{l}\text { Peru } \\
\end{array}$ & 2.5 & 1.7 & Kyrgyz Republic $^{\top}$ & 3.6 & 1.1 \\
\hline Suriname & 2.1 & 1.7 & Belarus $^{1}$ & 2.9 & 0.9 \\
\hline Colombia & 3.8 & 1.4 & Ukraine $^{1}$ & 2.5 & 0.8 \\
\hline Brazil & 1.9 & 1.1 & Russian Federation $^{1}$ & 1.8 & 0.7 \\
\hline Paraguay $^{2}$ & 2.1 & 1.0 & North Africa & & \\
\hline Guyana $^{1}$ & 3.1 & 0.8 & Libya & - & 7.8 \\
\hline Jamaica $^{T}$ & 4.8 & - & Algeria & 5.1 & 2.2 \\
\hline Western Europe & & & Sub-Saharan Africa & & \\
\hline Bosnia and Herzogovina & 3302.1 & 43.4 & Central African Republic & 5.8 & 3.7 \\
\hline Macedonia & 25.9 & 12.6 & Zaire & 8.0 & 3.7 \\
\hline Malta & 11.2 & 5.4 & Cameroon & 4.2 & 3.1 \\
\hline Luxembourg & 9.1 & 5.0 & Namibia & 8.0 & 3.0 \\
\hline Norway & 5.3 & 4.5 & Zimbabwe & 5.8 & 2.5 \\
\hline Iceland & 6.0 & 4.3 & Madagascar & 1.8 & 1.8 \\
\hline Croatia & 5.8 & 3.5 & Gambia & 5.4 & 1.5 \\
\hline Cyprus & 7.3 & 3.3 & Seychelles & - & 1.5 \\
\hline Greece & 4.6 & 2.8 & Sierra.Leone & 1.6 & 1.3 \\
\hline Ireland & 5.5 & 2.8 & Uganda & 2.9 & 1.3 \\
\hline UK & 4.9 & 2.7 & Malawi & 1.7 & 1.2 \\
\hline Turkey & 3.2 & 2.3 & Botswana & 1.7 & 1.1 \\
\hline Slovenia & 4.0 & 2.1 & Sudan $^{2}$ & 2.4 & 1.0 \\
\hline Austria & 2.5 & 2.0 & Kenya ${ }^{T}$ & 1.2 & 0.9 \\
\hline Sweden & 2.0 & 1.7 & Guinea $^{T}$ & 1.6 & 0.8 \\
\hline Denmark & 2.2 & 1.6 & Ghana $^{1}$ & 3.3 & 0.7 \\
\hline Portugal & 2.9 & 1.6 & Tunisia $^{T}$ & 1.2 & 0.6 \\
\hline Spain & 2.3 & 1.4 & South.Africa ${ }^{\mathrm{I}}$ & 1.2 & 0.3 \\
\hline Italy & 2.0 & 1.3 & Asia Pacific & & \\
\hline Finland & 1.6 & 1.2 & Macao, China & 77.7 & 43.7 \\
\hline France & 1.6 & 1.2 & Pakistan & 52.2 & 26.7 \\
\hline Germany $^{2}$ & 1.3 & 1.0 & Mongolia & 7.8 & 5.5 \\
\hline Netherlands $^{1}$ & 1.1 & 0.7 & Papua New Guinea & 10.7 & 4.5 \\
\hline Middle-East & & & Cambodia & 7.9 & 3.3 \\
\hline Oman & 4.4 & 3.0 & Japan & 2.5 & 2.9 \\
\hline Qatar & - & 2.0 & China & 6.5 & 2.6 \\
\hline Iran & 4.1 & 1.9 & Philippines & 5.5 & 2.3 \\
\hline Lebanon & 1.4 & 1.9 & New Zealand & 3.6 & 1.7 \\
\hline Kuwait & 2.1 & 1.6 & Korea, Rep. & 1.8 & 1.2 \\
\hline Syrian Arab Republic & 2.2 & 1.4 & Solomon.Islands $^{2}$ & 2.1 & 1.0 \\
\hline Bahrain $^{1}$ & 1.3 & 0.9 & Vietnam $^{2}$ & 2.0 & 1.0 \\
\hline Saudi Arabia ${ }^{\top}$ & 1.1 & 0.8 & Thailand & 1.9 & 1.0 \\
\hline Central and Eastern Europe & & & Hong.Kong & 1.5 & 0.9 \\
\hline Lithuania & 11.2 & 5.9 & Nepal $^{1}$ & 1.3 & 0.8 \\
\hline Romania & 10.7 & 5.2 & Australia & 1.3 & 0.7 \\
\hline Poland & 7.8 & 4.2 & Samoa $^{1}$ & 2.2 & - \\
\hline Yugoslavia & - & 4.1 & North America & & \\
\hline Slovak Republic & 9.2 & 4.1 & Canada & 2.5 & 1.3 \\
\hline Bulgaria & 7.9 & 2.8 & USA & 1.9 & 1.1 \\
\hline Latvia & 3.7 & 2.1 & & & \\
\hline Estonia & 4.1 & 1.9 & & & \\
\hline Hungary & 3.2 & 1.7 & & & \\
\hline Czech Republic $^{2}$ & 2.1 & 1.0 & & & \\
\hline
\end{tabular}


Table 4D: Countries with Potential for Expansion of Trade (P-A)

\begin{tabular}{|c|c|c|c|}
\hline Country & $(\mathbf{P}-\mathbf{A})_{\mathrm{ppp}}$ & Country & $(\mathbf{P}-\mathbf{A})_{\mathrm{ppp}}$ \\
\hline United Kingdom & 21600 & Nepal & 114.0 \\
\hline China & 16200 & Croatia & 112.2 \\
\hline Pakistan & 13100 & Slovenia & 111.6 \\
\hline USA & 11800 & Malta & 109.5 \\
\hline Japan & 5720.4 & Belarus & 106.5 \\
\hline Italy & 2107.2 & Lithuania & 101.6 \\
\hline Bosnia and herzegovina & 1799.1 & Syrian.Arab.republic & 97.9 \\
\hline Canada & 1729.6 & Turkmenistan & 96.2 \\
\hline Germany & 1439.8 & Uganda & 93.5 \\
\hline France & 1406.8 & Luxembourg & 88.6 \\
\hline Iran & 1384.0 & Macao, China & 85.5 \\
\hline Hong.kong & 1370.7 & Venezuela & 71.5 \\
\hline Philippines & 1221.7 & Cambodia & 64.6 \\
\hline Russian fed & 1199.0 & Azerbaijan & 62.3 \\
\hline Spain & 1098.6 & Kyrgyzstan & 58.4 \\
\hline Korea, rep. & 1031.7 & Peru & 55.6 \\
\hline Poland & 891.0 & Bahrain & 55.4 \\
\hline Turkey & 861.4 & Georgia & 55.1 \\
\hline Thailand & 804.5 & Cameroon & 51.4 \\
\hline Ireland & 803.7 & Latvia & 49.4 \\
\hline Greece & 559.9 & Papua.new.guinea & 47.4 \\
\hline Australia & 528.0 & Estonia & 45.4 \\
\hline Oman & 521.1 & Guatemala & 39.9 \\
\hline Norway & 469.3 & Costa rica & 37.6 \\
\hline Mexico & 443.1 & Iceland & 37.0 \\
\hline Sweden & 440.2 & Jamaica & 35.8 \\
\hline Brazil & 439.4 & Tajikistan & 35.2 \\
\hline New.Zealand & 372.8 & Zaire & 33.5 \\
\hline Denmark & 364.6 & El.salvador & 32.4 \\
\hline Kuwait & 349.6 & Macedonia, tfyr & 31.7 \\
\hline Austria & 348.7 & Tunisia & 27.7 \\
\hline Romania & 332.4 & Namibia & 26.8 \\
\hline Portugal & 311.3 & Kenya & 25.8 \\
\hline Ukraine & 305.3 & Ecuador & 24.7 \\
\hline Algeria & 305.1 & Lebanon & 21.0 \\
\hline Kazakhstan & 270.0 & N.Caledonia & 18.8 \\
\hline Uzbekistan & 262.6 & Guyana & 13.7 \\
\hline Viet nam & 250.1 & Gambia & 13.5 \\
\hline Finland & 232.8 & Malawi & 13.2 \\
\hline South.africa & 206.7 & Mongolia & 10.4 \\
\hline Cyprus & 200.4 & Paraguay & 9.9 \\
\hline Saudi arabia & 190.8 & Madagascar & 9.4 \\
\hline Hungary & 190.3 & Botswana & 8.8 \\
\hline Colombia & 190.0 & Guinea & 6.8 \\
\hline Czechoslovakia & 167.7 & Bolivia & 5.2 \\
\hline Bulgaria & 157.5 & Central African Republic & 4.9 \\
\hline Ghana & 152.6 & Solomon.islands & 4.0 \\
\hline Sudan & 149.6 & Sierra.Leone & 3.3 \\
\hline Slovakia & 132.9 & Samoa & 1.4 \\
\hline Netherlands & 117.2 & Suriname & 1.3 \\
\hline Zimbabwe & 114.8 & Maldives & 0.7 \\
\hline
\end{tabular}


Table 4E: Countries with Potential for Expansion of Trade (P-A)c

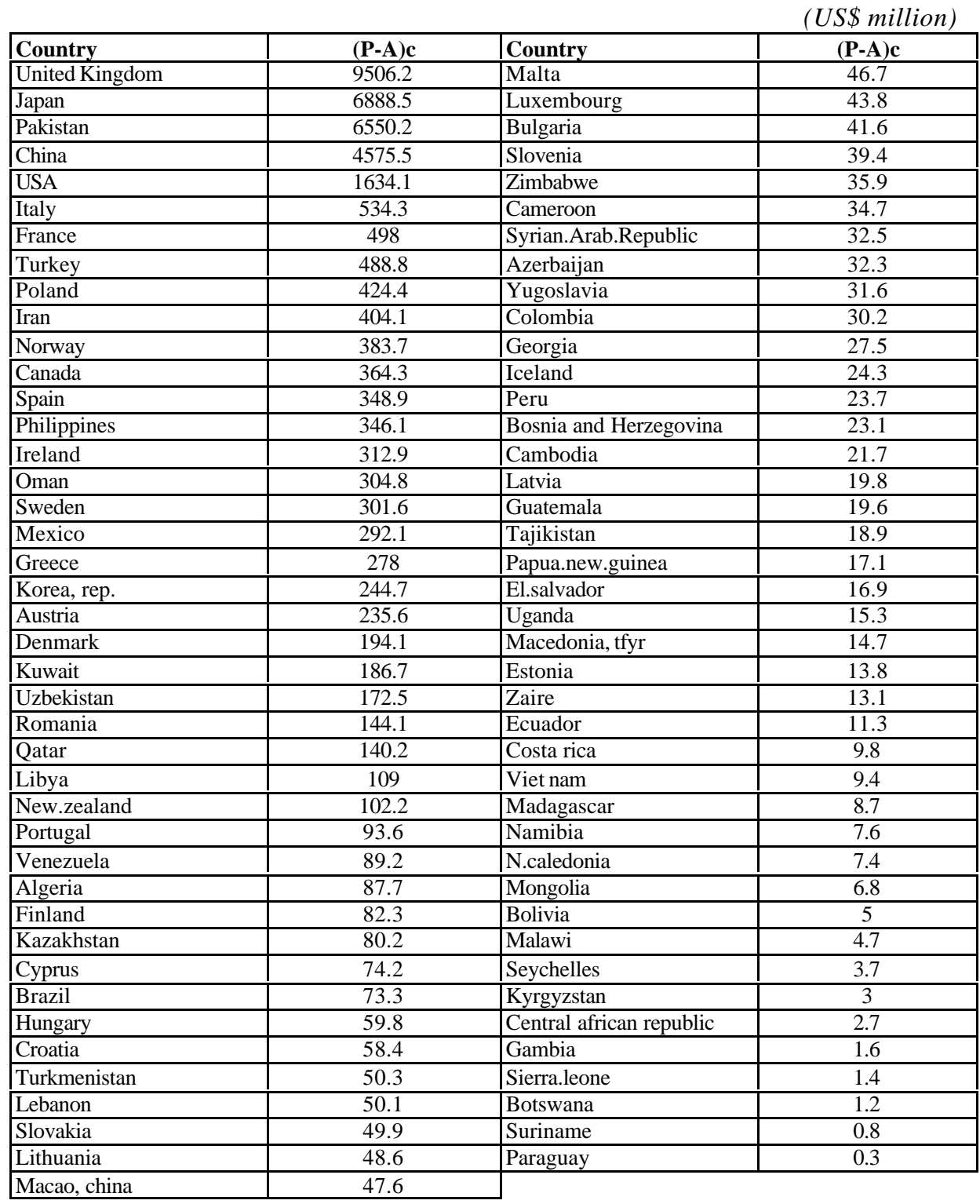


Table 4F:

Regional Distribution of Countries with Potential for Expansion of Trade* (P-A)(US\$mn)

\begin{tabular}{|c|c|c|c|c|c|}
\hline Country & (P-A)ppp & $(\mathbf{P}-\mathbf{A}) \mathbf{c}$ & Country & (P-A)ppp & $(\mathbf{P}-\mathbf{A}) \mathbf{c}$ \\
\hline North America & & & CIS & & \\
\hline USA & 11800 & 1634.1 & Uzbekistan & 262.6 & 172.5 \\
\hline Canada & 1729.6 & 364.3 & Kazakhstan & 270.0 & 80.2 \\
\hline Latin America & & & Turkmenistan & 96.2 & 50.3 \\
\hline Mexico & 443.1 & 292.1 & Azerbaijan & 62.3 & 32.3 \\
\hline Venezuela & 71.5 & 89.2 & Georgia & 55.1 & 27.5 \\
\hline Brazil & 439.4 & 73.3 & Tajikistan & 35.2 & 18.9 \\
\hline Colombia & 190.0 & 30.2 & Kyrgyzstan & 58.4 & 3.0 \\
\hline Peru & 55.6 & 23.7 & Belarus & 106.5 & -3.8 \\
\hline Guatemala & 39.9 & 19.6 & Ukraine $^{1}$ & 305.3 & -46.4 \\
\hline El Salvador & 32.4 & 16.9 & Russian Federation $^{1}$ & 1199.0 & -359.0 \\
\hline Ecuador & 24.7 & 11.3 & North Africa & & \\
\hline Costa Rica & 37.6 & 9.8 & Libya & - & 109.0 \\
\hline Bolivia & 5.2 & 5.0 & Algeria & 305.1 & 87.7 \\
\hline Suriname & 1.3 & 0.8 & Sub-Saharan Africa & & \\
\hline Paraguay & 9.9 & 0.3 & Zimbabwe & 114.8 & 35.9 \\
\hline Jamaica & 35.8 & - & Cameroon & 51.4 & 34.7 \\
\hline Guyana $^{1}$ & 13.7 & -1.6 & Uganda & 93.5 & 15.3 \\
\hline Western Europe & & & Zaire & 33.5 & 13.1 \\
\hline $\mathrm{UK}$ & 21600.0 & 9506.2 & Madagascar & 9.4 & 8.7 \\
\hline Italy & 2107.2 & 534.3 & Namibia & 26.8 & 7.6 \\
\hline France & 1406.8 & 498.0 & Malawi & 13.2 & 4.7 \\
\hline Turkey & 861.4 & 488.8 & Seychelles & - & 3.7 \\
\hline Norway & 469.3 & 383.7 & Central African Republic & 4.9 & 2.7 \\
\hline Spain & 1098.6 & 348.9 & Gambia & 13.5 & 1.6 \\
\hline Ireland & 803.7 & 312.9 & Sierra.Leone & 3.3 & 1.4 \\
\hline Sweden & 440.2 & 301.6 & Botswana & 8.8 & 1.2 \\
\hline Greece & 559.9 & 278.0 & Guinea $^{1}$ & 6.8 & -2.8 \\
\hline Austria & 348.7 & 235.6 & Sudan $^{1}$ & 149.6 & -5.1 \\
\hline Denmark & 364.6 & 194.1 & Kenya $^{\top}$ & 25.8 & -17.3 \\
\hline Portugal & 311.3 & 93.6 & Ghana' & 152.6 & -18.8 \\
\hline Finland & 232.8 & 82.3 & Tunisia $^{\top}$ & 27.7 & -52.0 \\
\hline Cyprus & 200.4 & 74.2 & South.Africa ${ }^{1}$ & 206.7 & -927.2 \\
\hline Croatia & 112.2 & 58.4 & Asia-Pacific & & \\
\hline Malta & 109.5 & 46.7 & Japan & 5720.4 & 6888.5 \\
\hline Luxembourg & 88.6 & 43.8 & Pakistan & 13100.0 & 6550.2 \\
\hline Slovenia & 111.6 & 39.4 & China & 16200.0 & 4575.5 \\
\hline Yugoslavia & - & 31.6 & Philippines & 1221.7 & 346.1 \\
\hline Iceland & 37.0 & 24.3 & Korea, Rep. & 1031.7 & 244.7 \\
\hline Bosnia and Herzogovina & 1799.1 & 23.1 & New Zealand & 372.8 & 102.2 \\
\hline Macedonia & 31.7 & 14.8 & Macao, China & 85.5 & 47.6 \\
\hline Germany & 1439.8 & -170.0 & Cambodia & 64.6 & 21.7 \\
\hline Netherlands $^{1}$ & 117.2 & -391.2 & Papua New Guinea & 47.4 & 17.1 \\
\hline Middle-East & & & Vietnam & 250.1 & 9.4 \\
\hline Iran & 1384.0 & 404.1 & Mongolia & 10.4 & 6.8 \\
\hline Oman & 521.1 & 304.8 & Solomon.Islands $^{2}$ & 4.0 & 0.03 \\
\hline Kuwait & 349.6 & 186.7 & Maldives ${ }^{1}$ & 0.7 & -8.4 \\
\hline Qatar & - & 140.3 & Thailand & 804.5 & -37.3 \\
\hline Lebanon & 21.0 & 50.1 & Nepal $^{1}$ & 114.0 & -82.7 \\
\hline Syrian Arab Republic & 97.9 & 32.5 & Hong.Kong & 1370.7 & -407.5 \\
\hline Bahrain & 55.4 & -19.9 & Australia & 528.0 & -418.2 \\
\hline Saudi Arabia ${ }^{1}$ & 190.8 & -279.4 & Samoa & 1.4 & - \\
\hline \multicolumn{6}{|c|}{ Central and Eastern Europe } \\
\hline Poland & 891.0 & 424.4 & & & \\
\hline Romania & 332.4 & 144.1 & & & \\
\hline Hungary & 190.3 & 59.8 & \multirow{7}{*}{\multicolumn{3}{|c|}{$\begin{array}{l}\text { *-ranked within regions according to }(\mathrm{P}-\mathrm{A})_{\mathrm{c}} \text {; } \\
\text { 1-potential according to }(\mathrm{P}-\mathrm{A}) \mathrm{ppp} \text { but overtraded according to }(\mathrm{P}-\mathrm{A}) \mathrm{c} \\
\text { 2-potential according to }(\mathrm{P}-\mathrm{A})_{\mathrm{ppp}} \text { but insignificant according to }(\mathrm{P}-\mathrm{A})_{\mathrm{c}}\end{array}$}} \\
\hline Slovak Republic & 132.9 & 49.9 & & & \\
\hline Bulgaria & 157.5 & 41.6 & & & \\
\hline Latvia & 49.4 & 19.8 & & & \\
\hline Estonia & 45.4 & 13.8 & & & \\
\hline Lithuania & 101.6 & 48.6 & & & \\
\hline Czech Republic ${ }^{1}$ & 167.7 & -5.6 & & & \\
\hline
\end{tabular}


Table 5A : Countries where India has Exceeded its Trade Potential (P/A)

\begin{tabular}{|c|c|c|}
\hline Country & $(\mathbf{P} / \mathbf{A})_{\mathrm{ppp}}$ & $(\mathbf{P} / \mathbf{A})_{c}$ \\
\hline Argentina & 0.7 & 0.5 \\
\hline Australia & - & 0.7 \\
\hline Bahrain & - & 0.9 \\
\hline Belarus & - & 0.9 \\
\hline Belgium & 0.2 & 0.1 \\
\hline Benin & 0.1 & 0.1 \\
\hline Burkina Faso & 0.6 & 0.4 \\
\hline Chile & 0.7 & 0.4 \\
\hline Congo & 0.1 & 0.3 \\
\hline Cote Divoire & 0.3 & 0.3 \\
\hline Djibouti & 0.3 & 0.2 \\
\hline Ethiopia & 0.3 & 0.1 \\
\hline Gabon & 0.5 & 0.5 \\
\hline Ghana & - & 0.7 \\
\hline Guinea & - & 0.8 \\
\hline Guyana & - & 0.8 \\
\hline Hong Kong & - & 0.9 \\
\hline Indonesia & 0.8 & 0.4 \\
\hline Israel & 0.8 & 0.6 \\
\hline Jordan & 0.2 & 0.2 \\
\hline Kenya & - & 0.9 \\
\hline Liberia & - & 0.2 \\
\hline Malaysia & 0.5 & 0.3 \\
\hline Maldives & - & 0.7 \\
\hline Mali & 0.2 & 0.2 \\
\hline Mauritania & 0.6 & 0.3 \\
\hline Mauritius & 0.9 & 0.3 \\
\hline Morocco & 0.4 & 0.3 \\
\hline Mozambique & 0.4 & 0.3 \\
\hline Nepal & - & 0.8 \\
\hline Netherlands & - & 0.7 \\
\hline Niger & 0.3 & 0.2 \\
\hline Nigeria & 0.8 & 0.7 \\
\hline Panama & 0.2 & 0.2 \\
\hline Russian Fed & - & 0.7 \\
\hline Saudi Arabia & - & 0.8 \\
\hline Senegal & 0.2 & 0.2 \\
\hline Singapore & 0.5 & 0.3 \\
\hline South Africa & - & 0.3 \\
\hline Sri Lanka & 1.0 & 0.5 \\
\hline Switzerland & 0.1 & 0.1 \\
\hline Tanzania & 0.5 & 0.7 \\
\hline Togo & 0.4 & 0.2 \\
\hline Tunisia & - & 0.6 \\
\hline Ukraine & - & 0.8 \\
\hline Uruguay & 0.9 & 0.7 \\
\hline Vanuatu & 0.1 & 0.04 \\
\hline Yemen & 0.2 & 0.4 \\
\hline Zambia & 0.7 & 0.9 \\
\hline
\end{tabular}


Table 5B: Countries where India has Exceeded its Trade Potential (P-A)

(US\$ million)

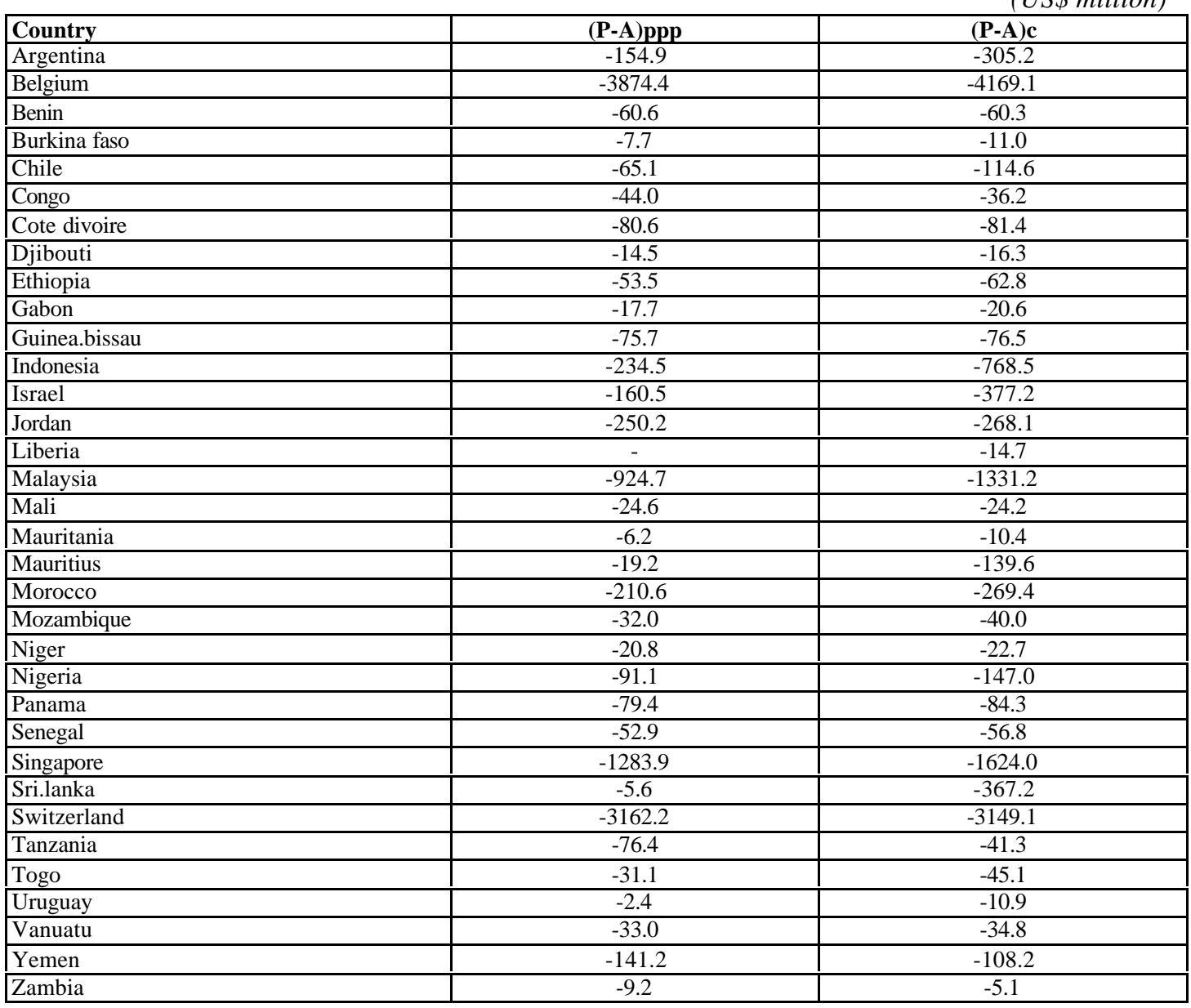


Table 5C:

\section{Regional Distribution of Countries where India has Exceeded its Trade Potential (P/A)}

\begin{tabular}{|c|c|c|c|c|c|}
\hline & $(\mathbf{P} / \mathbf{A})_{\mathrm{ppp}}$ & $(\mathbf{P} / \mathbf{A})_{\mathrm{c}}$ & & $(\mathbf{P} / \mathbf{A})_{\mathrm{ppp}}$ & $(\mathbf{P} / \mathbf{A})_{c}$ \\
\hline Latin America & & & Sub-Saharan & & \\
\hline Uruguay & 0.9 & 0.7 & Benin & 0.1 & 0.1 \\
\hline Argentina & 0.7 & 0.5 & Burkina Faso & 0.6 & 0.4 \\
\hline Chile & 0.7 & 0.4 & Congo & 0.1 & 0.3 \\
\hline Panama & 0.2 & 0.2 & Cote divoire & 0.3 & 0.3 \\
\hline Northern Africa & & & Djibouti & 0.3 & 0.2 \\
\hline Morocco & 0.4 & 0.3 & Ethiopia & 0.3 & 0.1 \\
\hline Western Europe & & & Gabon & 0.5 & 0.5 \\
\hline Belgium & 0.2 & 0.1 & Mauritania & 0.6 & 0.3 \\
\hline Switzerland & 0.1 & 0.1 & Mali & 0.2 & 0.2 \\
\hline Asia & & & Mauritius & 0.9 & 0.3 \\
\hline Indonesia & 0.8 & 0.4 & Mozambique & 0.4 & 0.3 \\
\hline Malaysia & 0.5 & 0.3 & Niger & 0.3 & 0.2 \\
\hline Singapore & 0.5 & 0.3 & Nigeria & 0.8 & 0.7 \\
\hline Sri Lanka * & 1.0 & 0.5 & Senegal & 0.2 & 0.2 \\
\hline Maldives* & 1.0 & 0.7 & Tanzania & 0.5 & 0.7 \\
\hline Vanuatu & 0.1 & 0.04 & Togo & 0.4 & 0.2 \\
\hline Middle-East & & & Uruguay & 0.9 & 0.7 \\
\hline Israel & 0.8 & 0.6 & Zambia & 0.7 & 0.9 \\
\hline Jordan & 0.2 & 0.2 & Liberia & - & 0.2 \\
\hline Yemen & 0.2 & 0.4 & & & \\
\hline
\end{tabular}

$*_{-} \mathrm{P} / \mathrm{A}_{\mathrm{ppp}}=1$

Table 5D:

Regional Distribution of Countries where India has Exceeded its Trade Potential (P- A)

\begin{tabular}{|c|c|c|c|c|c|}
\hline & & & & \multicolumn{2}{|c|}{ (US\$ million) } \\
\hline & (P-A)ppp & $(\mathbf{P}-\mathbf{A}) \mathbf{c}$ & & (P-A)ppp & $\overline{(\mathbf{P}-\mathbf{A}) \mathrm{c}}$ \\
\hline Western Europe & & & Sub-Saharan Africa & & \\
\hline Belgium & $\begin{array}{l}-3874.4 \\
\end{array}$ & -4169.1 & Benin & -60.6 & $\begin{array}{l}-60.3 \\
\end{array}$ \\
\hline Switzerland & -3162.2 & -3149.1 & Burkina Faso & -7.7 & -11.0 \\
\hline Middle-East & & & Congo & -44.0 & -36.2 \\
\hline Israel & -160.5 & -377.2 & Cote Divoire & -80.6 & -81.4 \\
\hline Jordan & -250.2 & -268.1 & Djibouti & -14.5 & -16.3 \\
\hline Yemen & -141.2 & -108.2 & Ethiopia & -53.5 & -62.8 \\
\hline Latin America & & & Gabon & -17.7 & -20.6 \\
\hline Argentina & -154.9 & -305.2 & Mauritania & -6.2 & -10.4 \\
\hline Uruguay & -2.4 & -10.9 & Mali & -24.6 & -24.2 \\
\hline Chile & -65.1 & -114.6 & Mauritius & -19.2 & -139.6 \\
\hline Panama & -79.4 & -84.3 & Mozambique & -32.0 & -40.1 \\
\hline Asia Pacific & & & Niger & -20.8 & -22.7 \\
\hline Indonesia & -234.5 & -768.5 & Nigeria & -91.1 & -147.0 \\
\hline Singapore & -1283.9 & -1624.0 & Senegal & -52.9 & -56.8 \\
\hline Malaysia & -924.7 & -1331.2 & Tanzania & -76.4 & -41.3 \\
\hline Sri.Lanka & -5.6 & -367.2 & Togo & -31.1 & -45.1 \\
\hline Vanuatu & -33.0 & -34.8 & Zambia & -9.2 & -5.1 \\
\hline Northern Africa & & & Guinea.bissau & -75.7 & -76.5 \\
\hline Morocco & -210.6 & -269.4 & Liberia & - & -14.7 \\
\hline
\end{tabular}


Table 6A: Trade Potential: With Regional Groupings in Asia * (P/A)

\section{GCC}

\begin{tabular}{|l|c|c|}
\hline Country & $(\mathbf{P} / \mathbf{A}) \mathbf{p p p}$ & $(\mathbf{P} / \mathbf{A})_{\mathrm{C}}$ \\
\hline Oman & 4.4 & 3.0 \\
\hline Qatar & - & 2.0 \\
\hline Kuwait & 2.1 & 1.6 \\
\hline Bahrain & 1.3 & 0.9 \\
\hline Saudi Arabia & 1.1 & 0.8 \\
\hline UAE & - & - \\
\hline
\end{tabular}

*- ranked according to $(\mathrm{P} / \mathrm{A})_{\mathrm{c}}$
ASEAN

\begin{tabular}{|l|c|c|}
\hline Country & $(\mathbf{P} / \mathbf{A}) \mathbf{p p p}$ & $(\mathbf{P} / \mathbf{A})_{\mathbf{C}}$ \\
\hline Cambodia & 7.9 & 3.3 \\
\hline Philippines & 5.5 & 2.3 \\
\hline Vietnam & 2.0 & 1.0 \\
\hline Thailand & 1.9 & 1.0 \\
\hline Indonesia & 0.8 & 0.4 \\
\hline Malaysia & 0.5 & 0.3 \\
\hline Singapore & 0.5 & 0.3 \\
\hline Laos & - & - \\
\hline Myanmar & - & - \\
\hline Brunei & - & - \\
\hline
\end{tabular}

SAARC

\begin{tabular}{|l|c|c|}
\hline Country & $(\mathbf{P} / \mathbf{A}) \mathbf{p p p}$ & $(\mathbf{P} / \mathbf{A})_{\mathbf{C}}$ \\
\hline Pakistan & 52.2 & 26.7 \\
\hline Nepal & 1.3 & 0.8 \\
\hline Maldives & 1.0 & 0.7 \\
\hline Sri Lanka & 1.0 & 0.5 \\
\hline Bangladesh & - & - \\
\hline Bhutan & - & - \\
\hline
\end{tabular}

Table 6B: Trade Potential: With Regional Groupings in Asia * (P-A)

GCC

\begin{tabular}{|l|c|c|}
\hline Country & (P-A)ppp & (P-A)c \\
\hline Oman & 521.1 & 304.8 \\
\hline Kuwait & 349.6 & 186.7 \\
\hline Qatar & - & 140.2 \\
\hline Bahrain & 55.4 & -19.9 \\
\hline Saudi Arabia & 190.8 & -279.4 \\
\hline UAE & - & - \\
\hline
\end{tabular}

*- ranked according to $(\mathrm{P} / \mathrm{A})_{\mathrm{c}}$
ASEAN

\begin{tabular}{|l|c|c|}
\hline Country & (P-A)ppp & $(\mathbf{P - A}) \mathbf{c}$ \\
\hline Philippines & 1221.7 & 346.1 \\
\hline Cambodia & 64.6 & 21.7 \\
\hline Vietnam & 250.1 & 9.4 \\
\hline Thailand & 804.5 & -37.3 \\
\hline Indonesia & -234.5 & -768.5 \\
\hline Malaysia & -924.7 & -1331.2 \\
\hline Singapore & -1283.9 & -1624.0 \\
\hline Laos & - & - \\
\hline Myanmar & - & - \\
\hline Brunei & - & - \\
\hline
\end{tabular}
SAARC

\begin{tabular}{|l|c|c|}
\hline Country & (P-A)ppp & (P-A)c \\
\hline Pakistan & 13100 & 6550.2 \\
\hline Maldives & 0.7 & -8.4 \\
\hline Nepal & 114.0 & -82.7 \\
\hline Sri Lanka & -5.6 & -367.2 \\
\hline Bangladesh & - & - \\
\hline Bhutan & - & - \\
\hline
\end{tabular}




\section{Annex}

Table I: Share of India and Selected East Asian Countries in World Trade

\begin{tabular}{|l|c|c|}
\hline \multicolumn{1}{|c|}{ Country } & Exports & Trade \\
\hline India & 0.8 & 0.8 \\
\hline China & 5.1 & 4.8 \\
\hline Indonesia & 0.6 & 0.5 \\
\hline Korea & 2.5 & 2.4 \\
\hline Malaysia & 1.5 & 1.3 \\
\hline Thailand & 1.1 & 1.0 \\
\hline
\end{tabular}

\section{Table II: List of sample countries:}

\begin{tabular}{|c|c|c|c|}
\hline Albania & Czechoslovakia & Kazakastan & Qatar \\
\hline Algeria & Denmark & Kenya & Romania \\
\hline Andorra & Dominica & Kiribati & Russian Fed \\
\hline Antigua and Barbuda & Dominican Republic & Korea Rep & Saudi Arabia \\
\hline Argentina & Ecuador & Latvia & Senegal \\
\hline Armenia & Egypt & Lebanon & Singapore \\
\hline Australia & El Slavador & Lithuania & Slovakia \\
\hline Austria & Estonia & Luxembourg & Slovenia \\
\hline Azerbaijan & Ethiopia & Macau & South Africa \\
\hline Bahamas & Fiji & Macedonia & South Africa C.U \\
\hline Bahrain & Finland & Madagascar & Spain \\
\hline Bangladesh & France & Malaysia & Sri Lanka \\
\hline Barbados & Gabon & Maldives & St. Kitts and Nevis \\
\hline Belarus & Gambia & Mali & St. Vct and Grenadines \\
\hline Belgium & Georgia & Malta & Sudan \\
\hline Belgium-luxembourg & Germany & Mauritius & Suriname \\
\hline Belize & Ghana & Mexico & Swaziland \\
\hline Benin & Greece & Moldova & Sweden \\
\hline Bhutan & Greenland & Mongolia & Switzerland \\
\hline Bolivia & Grenada & Morocco & Tajikistan \\
\hline Botswana & Guatemala & Mozambique & Tanzania \\
\hline Brazil & Guinea & Nepal & Thailand \\
\hline Brunei Dar. & Haiti & Netherlands & Togo \\
\hline Bulgaria & Honduras & New Zealand & Tonga \\
\hline Burundi & Hong Kong & Nicaragua & Trinidad and Tobago \\
\hline Cameroon & Hungary & Niger & Tunisia \\
\hline Canada & Iceland & Nigeria & Turkey \\
\hline Cape Verde & India & Norway & Turkmenistan \\
\hline Chile & Indonesia & Oman & U.K \\
\hline China & Iran & Panama & U.S.A \\
\hline Colombia & Ireland & Papua New Guinea & UAE \\
\hline Comoros & Israel & Paraguay & Uganda \\
\hline Costa Rica & Italy & Peru & Uruguay \\
\hline Cote divoire & Jamaica & Philippines & Vanautu \\
\hline Croatia & Japan & Poland & Venezuela \\
\hline \multirow[t]{3}{*}{ Cyprus } & Jordan & Portugal & Yugoslavia \\
\hline & & & Zambia \\
\hline & & & Zimbabwe \\
\hline
\end{tabular}


Table III: Regional Trading Arrangements

\begin{tabular}{|c|c|c|c|c|c|c|}
\hline APEC & NAFTA & EEA & AFTA & SAPTA & Sparteca & $\begin{array}{l}\text { EFTA } \\
\text { Iceland }\end{array}$ \\
\hline Australia & Canada & Austria & Brunei & Bangladesh & Australia & $\begin{array}{l}\text { Iceland } \\
\text { Liechtenstein }\end{array}$ \\
\hline Brunei & Mexico & Belgium & Indonesia & Bhutan & Cook Island & \\
\hline Canada & US & Denmark & Malaysia & India & Fiji & Norway \\
\hline Chile & & Finland & Philippines & Maldives & Kiribati & Switzerland \\
\hline China & & France & Thailand & Nepal & Marshall Islands & \\
\hline Hong Kong & & Greece & Singapore & Pakistan & Micronesia & \\
\hline Indonesia & & Luxembourg & Vietnam & Sri Lanka & Nauru & \\
\hline Japan & & Iceland & & & New Zealand & \\
\hline Korea & & Italy & & & Niue & \\
\hline Malaysia & & Ireland & & & Papua New Guinea & \\
\hline Mexico & & Netherlands & & & Solomon Island & \\
\hline N. Zealand & & Norway & & & Tonga & \\
\hline P.N Guinea & & Portugal & & & Tuvalu & \\
\hline Peru & & Spain & & & Vanuatu & \\
\hline Philippines & & Sweden & & & Western Samoa & \\
\hline Russia & & Germany & & & & \\
\hline Singapore & & UK & & & & \\
\hline Thailand & & & & & & \\
\hline & & & & & & \\
\hline Vietnam & & & & & & \\
\hline ANZ CER & GCC & CEFTA & ANDEAN & ECOWAS & $\mathbf{B A}$ & \\
\hline Australia & Bahrain & Bulgaria & Bolivia & Benin & Bangladesh & \\
\hline N.Zealand & Kuwait & Czechoslovakia & Colombia & Burkina Faso & China & \\
\hline & Oman & Hungary & Ecuador & Cape Verde & India & \\
\hline & Qatar & Poland & Peru & Cote Divoire & Korea & \\
\hline & S.Arabia & Romania & Venezuela & Gambia & Laos & \\
\hline & UAE & Slovak & & Ghana & Philippines & \\
\hline & & Slovenia & & Guinea & Sri Lanka & \\
\hline & & & & Guinea Bissau & Thailand & \\
\hline & & & & Liberia & & \\
\hline & & & & Mali & & \\
\hline & & & & Mauritania & & \\
\hline & & & & Niger & & \\
\hline & & & & Nigeria & & \\
\hline & & & & Senegal & & \\
\hline & & & & Sierra Leone & & \\
\hline & & & & Togo & & \\
\hline
\end{tabular}

